\title{
Long-term stability of records of fallout radionuclides in the sediments of Brotherswater, Cumbria (UK)
}

\author{
P. Semertzidou • G. T. Piliposian • R. C. Chiverrell • P. G. Appleby
}

Received: 4 September 2017 / Accepted: 4 September 2018/Published online: 12 December 2018

(C) The Author(s) 2018

\begin{abstract}
Results from a recent multi-core study of ${ }^{137} \mathrm{Cs}$ and ${ }^{210} \mathrm{~Pb}$ in Brotherswater, Cumbria, are compared with those from two similar multi-core studies carried out at the same lake in 1976/1977 and $1988 / 1989$. The purpose of this new study was to assess of the long-term stability of fallout records of these radionuclides in the sediments of Brotherswater and their reliability as tools for dating the sediments. Six cores were taken from four different areas of the lake, similar to those used in the earlier studies. Dried sediment samples from each core were analysed by gamma spectrometry for ${ }^{210} \mathrm{~Pb},{ }^{226} \mathrm{Ra},{ }^{137} \mathrm{Cs}$ and ${ }^{241} \mathrm{Am}$ following a similar protocol to that used in the $1988 / 1989$ study. The ${ }^{137} \mathrm{Cs}$ results graphically illustrate the progressive burial of a peak in concentrations recording the 1963 fallout maximum from the atmospheric testing of nuclear weapons, and its subsequent reduction due to radioactive decay. The
\end{abstract}

Electronic supplementary material The online version of this article (https://doi.org/10.1007/s10933-018-0055-7) contains supplementary material, which is available to authorized users.

P. Semertzidou $(\bowtie) \cdot$ G. T. Piliposian · P. G. Appleby Department of Mathematical Sciences, Environmental Radioactivity Research Centre, University of Liverpool, Liverpool, UK

e-mail: semergt@liv.ac.uk

R. C. Chiverrell

School of Environmental Sciences, Roxby Building,

University of Liverpool, Liverpool, UK post-1986 cores are characterised by the appearance and burial of a second peak recording fallout from the 1986 Chernobyl accident. Identification of the 1963 ${ }^{137} \mathrm{Cs}$ peak in post-1986 cores was confirmed by the co-presence of traces of ${ }^{241} \mathrm{Am}$, also a product of nuclear weapons test fallout. In both the 1988/1989 study and the present study, ${ }^{210} \mathrm{~Pb}$ dates calculated using the CRS model for the most part placed 1963 and 1986 at depths very similar to those determined from the ${ }^{137} \mathrm{Cs}$ records. The maintenance of this agreement over a period of more than two decades provides evidence of the reliability of sediment records in this lake and the validity of models used to interpret them. The ${ }^{137}$ Cs records were too indistinct and 1963 too recent to make similar comparisons in the case of the 1976/1977 cores. Agreement between ${ }^{210} \mathrm{~Pb}$ and ${ }^{137} \mathrm{Cs}$ dates was best at sites where the net rate of supply of ${ }^{210} \mathrm{~Pb}$ to the sediment record was comparable to the atmospheric flux. Small but significant discrepancies were observed at sites where the ${ }^{210} \mathrm{~Pb}$ supply rate greatly exceeded the atmospheric flux, most probably due to additional time-dependent inputs from the catchment, or post-depositional sediment redistribution within the lake.

Keywords ${ }^{210} \mathrm{~Pb} \cdot{ }^{137} \mathrm{Cs} \cdot$ Brotherswater $\cdot$ Lake sediments $\cdot$ Radiometric dating 


\section{Introduction}

Measurements of fallout ${ }^{137} \mathrm{Cs}$ and ${ }^{210} \mathrm{~Pb}$ in sediment cores from Brotherswater, Cumbria, have been made during the course of a number of different studies, dating back to the early 1970s. The first reported study was carried out by Winifred Pennington (Freshwater Biological Association, Ambleside, Cumbria). Two cores collected in 1974/1975 were analysed for weapons fallout ${ }^{137} \mathrm{Cs}$. The first, BW1, was from a site close to the present inflow. The second, BRW, was from a site on the western side of the lake. The results from BW1 were published in Pennington (1981). A more detailed investigation was carried out in 1976/1977 by John Eakins and Roger Cambray (AERE Harwell). Sediment cores from five different locations in the lake were analysed for ${ }^{210} \mathrm{~Pb},{ }^{226} \mathrm{Ra}$ and ${ }^{137} \mathrm{Cs}$ as part of a study of the transfer of radionuclides from the catchment to the lake (Eakins et al. 1981, 1984). A further multi-core study was carried out in 1988/1989 during an investigation into the impact of fallout from the 1986 Chernobyl accident. In this case a total of six cores were collected from the same areas of the lake as those sampled in $1976 / 1977$ and analysed for ${ }^{210} \mathrm{~Pb},{ }^{226} \mathrm{Ra},{ }^{137} \mathrm{Cs},{ }^{134} \mathrm{Cs}$ and ${ }^{241} \mathrm{Am}$ in the Liverpool University Environmental Radioactivity Research Centre. The results were reported in Bonnett et al. (1992) and Hilton et al. (1992).

The techniques for dating recent sediments developed in those years have now been used in literally thousands of studies for measuring lake sediment accumulation rates and reconstructing histories of environmental change from the environmental records stored in these natural archives. Dating by ${ }^{137} \mathrm{Cs}$ assumes that particular events such as the 1963 fallout maximum from the atmospheric testing of nuclear weapons or the 1986 Chernobyl reactor fire leave identifiable chronostratigraphic features at the 1963 or 1986 depths in the sediment record. Dating by ${ }^{210} \mathrm{~Pb}$ assumes that changes to the initial concentrations of sediment samples deposited on the bed of the lake are predominantly due to radioactive decay. The amount of time since deposition can then be calculated by comparing the current (measured) ${ }^{210} \mathrm{~Pb}$ activity to the initial (estimated) activity. There are two simple models for calculating the initial concentrations, the CRS (Constant Rate of ${ }^{210} \mathrm{~Pb}$ Supply) and CIC (Constant Initial ${ }^{210} \mathrm{~Pb}$ Concentration) models
(Appleby and Oldfield 1978; Robbins 1978). Since in many cases neither of these assumption is fully satisfied throughout the ${ }^{210} \mathrm{~Pb}$ time-span ( $\sim 130$ years) these models will often need to be applied in a piecewise way to different parts of the record (Appleby 2001).

One of the central assumptions of paleolimnology is that sediment records formed at the sediment/water interface and buried beneath successive layers of sediment faithfully record the source event and are not significantly distorted by different transport pathways. Further, the records are preserved relatively intact and not subject to significant subsequent degradation by diagenesis or post-depositional mobility. Although this is evidently not the case for more soluble species such as ${ }^{137} \mathrm{Cs}$, traces of which are often found in sediments predating by many decades the 1950 s introduction of this artificial radionuclide into the global environment, it is thought to be reasonably valid for less soluble species such as ${ }^{210} \mathrm{~Pb}$. Although some modification is almost inevitable, a key issue in paleolimnological studies is the extent to which these processes may have affected essential features of the record. Are peaks in ${ }^{137} \mathrm{Cs}$ concentrations reliable indicators of known fallout events? Do delayed inputs of fallout ${ }^{210} \mathrm{~Pb}$ via the catchment significantly distort the fallout record? The existence of the above two earlier multi-core studies at Brotherswater spanning a period of four decades offers a unique opportunity to assess the long-term stability of sediment records, and in particular the reliability of their dating by ${ }^{210} \mathrm{~Pb}$ and ${ }^{137} \mathrm{Cs}$. With this objective in mind, further cores were recovered from Brotherswater during 2011-2014 at similar locations to those sampled in the earlier studies and their ${ }^{210} \mathrm{~Pb}$ and ${ }^{137} \mathrm{Cs}$ records determined and compared with those from the 1970s and 1980s.

\section{Study site}

Brotherswater is a small $\left(0.18 \mathrm{~km}^{2}\right)$, upland (altitude $158 \mathrm{~m}$ ) lake in the Hartsop valley, in Cumbria, North West England, about $13 \mathrm{~km}$ north of Windermere. It has a large catchment $\left(13 \mathrm{~km}^{2}\right)$ and large catchmentto-lake area ratio (72). The catchment drains northwards by way of a several small becks that merge to form a single input stream (Kirkstone beck) near the south-western corner of Brotherswater. The outlet stream, Goldrill Beck, leaves the lake at the northwestern corner and drains northwards into Ullswater. 
The basic physiographic parameters of the catchment and its lake are given in Table 1. Sediments mainly enter through the single inflow. The bathymetry of the lake is dominated by a central flat profundal zone with a maximum depth of $17 \mathrm{~m}$. Brotherswater is classified on the meso/oligo-trophic boundary (Maberly et al. 2011) and develops weak summer thermal stratification.

\section{Historical studies}

The 1970s and 1980s Brotherswater sediment cores were collected from 5 different sites in the lake:

- Site 1 at the southern end of the lake near the inflow, at depths of around $8 \mathrm{~m}$.

- Site 2 half way up on the western side of the lake, at depths of between 5 and $11 \mathrm{~m}$.

- Site 3 in the central basin at a depth of around $16 \mathrm{~m}$.

- Site 4 on the eastern side of the lake, at depths of between 7 and $9 \mathrm{~m}$.

- Site 5 at the northern end of the lake near the outflow, at depths of between 4 and $5 \mathrm{~m}$.

The original ${ }^{137} \mathrm{Cs}$ data for the 1970 s cores are recorded in Roger Cambray's logbook, a copy of which is held in the Liverpool University ERRC (Environmental Radioactivity Research Centre). Since there are a number of issues concerning the data that are relevant to an understanding of the results, we give here a brief description of the original data and the way in which it has been collected and processed. Core BW1, collected in 1974 from site 1, was actually an amalgamation of three adjacent cores, obtained by combining corresponding $1-\mathrm{cm}$ slices

Table 1 Brotherswater catchment-lake parameters

\begin{tabular}{ll}
\hline Location & $54.5^{\circ} \mathrm{N}, 2.9^{\circ} \mathrm{W}$ \\
Catchment area & $13 \mathrm{~km}^{2}$ \\
Altitude range & $158-800 \mathrm{~m}$ \\
Rainfall & $2530 \mathrm{~mm}$ \\
Lake area & $1.8 \times 10^{5} \mathrm{~m}^{2}$ \\
Maximum depth & $17 \mathrm{~m}$ \\
Mean depth & $6.6 \mathrm{~m}$ \\
Lake volume & $2.1 \times 10^{6} \mathrm{~m}^{3}$ \\
Catchment area to lake ratio & 72 \\
\hline
\end{tabular}

from each core. In the case of core BRW (site 2), collected a year later in 1975, the analyses were carried out on samples from a single core sliced at 1-cm intervals. In both cases, Cambray's logbook reports the sample weight (gDW), total activity (pCi) and volumetric specific activity $\left(\mathrm{pCi} \mathrm{cm}^{-2}\right.$ ) of each slice. To facilitate comparison with other studies mass specific activities $\left(\mathrm{Bq} \mathrm{kg}^{-1}\right)$ and dry bulk densities $\left(\mathrm{g} \mathrm{cm}^{-3}\right)$ have been calculated from the sample weights and total activities. The calculations have been corrected for the fact that the internal diameter of the core tube was $5.08 \mathrm{~cm}$, not $5.3 \mathrm{~cm}$ as originally reported.

Cambray's logbook also records the original ${ }^{137} \mathrm{Cs}$ data for the 1976/1977 cores. For BW1/76 (site 1, collected in September 1976), and the 1977 cores $\mathrm{BWC}$ (site 3) and BWN (site 5), it gives the ${ }^{137} \mathrm{Cs}$ activity (pCi) and volumetric specific activity $\left(\mathrm{pCi} \mathrm{cm}^{-2}\right.$ ) for each 1-cm slice. Mass specific activities as $\mathrm{Bq} \mathrm{kg}^{-1}$ were determined using estimated values of the dry bulk density. For the uppermost $12 \mathrm{~cm}$ of the core these were given in graphical form in Eakins et al. (1981). At greater depths they were estimated from corresponding data for other nearby cores, scaled so as to yield the same radionuclide inventories as those given by Cambray. For cores BWW (site 2) and BWE (site 4) the logbook included dry weights, ${ }^{137} \mathrm{Cs}$ activities (pCi) and specific activities ( $\mathrm{pCi} \mathrm{g}^{-1}, \mathrm{pCi} \mathrm{cm}^{-2}$ ), from which ${ }^{137} \mathrm{Cs}$ activities $\mathrm{Bq} \mathrm{kg}{ }^{-1}$ and dry bulk densities as $\mathrm{g} \mathrm{cm}^{-3}$ could be calculated directly. ${ }^{210} \mathrm{~Pb}$ and ${ }^{226} \mathrm{Ra}$ analysis on the 1976/1977 cores were carried out by John Eakins at Harwell using alpha spectrometry. Although the original data are not available, the results are given in graphical form in Eakins et al. (1981, 1984). It is not clear whether these analyses were carried out on the same cores as those used for the ${ }^{137} \mathrm{Cs}$ analysis or on adjacent parallel cores.

In the 1988/1989 study a total of six cores were collected using a 1-m mini-Mackereth corer, BW88/2 in 1988 from site 2, and BW89/1-5 in August 1989 from sites $1-5$. The cores were sectioned at $1-\mathrm{cm}$ intervals and analysed for fallout radionuclides in the Liverpool University ERL (Environmental Radiometric Laboratory) following its standard protocol (see below). The results have been published in the UK Department of the Environment Research Reports (Bonnett et al. 1992; Hilton et al. 1992). Table 2 gives a list of cores collected during the 1976/1977 and 
Table 2 List of historical Brotherswater cores dated by ${ }^{210} \mathrm{~Pb}$ and ${ }^{137} \mathrm{Cs}$

\begin{tabular}{lllllll}
\hline Location & & \multicolumn{2}{l}{ 1976/1977 Study } & & \multicolumn{2}{l}{ 1988/1989 Study } \\
\cline { 5 - 6 } & & Core & Depth $(\mathrm{m})$ & & Core & Depth (m) \\
\hline Site 1 & Inlet & BW1/76 & 8.5 & & BW89/1 & 8.5 \\
Site 2 & Western & BWW & 7.5 & & BW88/2 & 11 \\
Site 3 & Central & BWC & 16 & & BW89/2 & 5 \\
Site 4 & Eastern & BWE & 7.5 & & BW89/3 & 16 \\
Site 5 & Northern & BWN & 4 & & BW89/5 & 4.5 \\
\hline
\end{tabular}

1988/1989 studies, dated by ${ }^{210} \mathrm{~Pb}$ and ${ }^{137} \mathrm{Cs}$. The 1974/75 cores BW1 and BRW (sites 1 and 2) were presumably collected from positions close to BW1/76 and BWW.

\section{Methods}

Core collection

Two sediment cores were collected from Brotherswater in 2011/2012 as part of a study of metal and sediment fluxes in the lake (Schillereff et al. 2016) using a short 8-cm diameter gravity corer designed to capture an intact sediment water-interface (Boyle 1995). The first (BW11-2) was from the western side of the lake (site 2) in $15.1 \mathrm{~m}$ water depth. The second (BW12-9) was from the central profundal zone (site 3) in $16.3 \mathrm{~m}$ water depth. A further four cores were collected in 2014 specifically for this study, BW14/E1 and BW14/E2 from the eastern side of the lake (site 4), and BW14/N1 and BW14/N2 from the northern end (site 5). The southwestern corner near the inlet stream (site 1) was not resampled due to the very rapid and irregular inputs of sediment from the catchment. Table 3 gives the water depths of each core and map coordinates (UK National Grid Reference). Following retrieval cores were kept upright to maintain a clear sediment/water interface, wrapped, sealed and stored in a refrigerator until ready for subsampling. This was done by extruding and slicing the sediment at $0.5-\mathrm{cm}$ intervals with care being taken to preserve all of the material. Each slice was then weighed wet, freeze dried, and weighed again dry to determine the water content and wet and dry bulk densities. The locations of all six core sites, together with those for the earlier studies, are shown in Fig. 1.

Radiometric analyses

Dried sediment samples from each core were analysed for ${ }^{210} \mathrm{~Pb},{ }^{226} \mathrm{Ra},{ }^{137} \mathrm{Cs}$ and ${ }^{241} \mathrm{Am}$ by direct gamma assay in the Liverpool University ERL (Environmental Radioactivity Laboratory) using Ortec HPGe GWL series well-type coaxial low background intrinsic germanium detectors (Appleby et al. 1986). Samples were placed in $5-\mathrm{cm}$ long by $1-\mathrm{cm}$ diameter nylon sample tubes sealed with flanged rubber Suba-Seals dipped in paraffin wax to prevent ${ }^{222} \mathrm{Rn}$ escape. ${ }^{210} \mathrm{~Pb}$ was determined via its gamma emissions at $46.5 \mathrm{keV}$, and ${ }^{226} \mathrm{Ra}$ by the $295 \mathrm{keV}$ and $352 \mathrm{keV} \gamma$-rays emitted by its daughter isotope ${ }^{214} \mathrm{~Pb}$ following 3 weeks storage to allow ${ }^{214} \mathrm{~Pb} /{ }^{226} \mathrm{Ra}$ radioactive equilibration. ${ }^{137} \mathrm{Cs}$ and ${ }^{241} \mathrm{Am}$ were measured by their emissions at
Table 3 List of 2011-2014 Brotherswater cores dated by ${ }^{210} \mathrm{~Pb}$ and ${ }^{137} \mathrm{Cs}$

\begin{tabular}{lllllll}
\hline Location & & Core & Date & Depth $(\mathrm{m})$ & \multicolumn{2}{c}{ Map coordinates } \\
\cline { 5 - 6 } & & & & & North & East \\
\hline Site 2 & West & BW11/2 & 2011 & 16.3 & 512678 & 340127 \\
Site 3 & Central & BW12/9 & 2012 & 15.1 & 512763 & 340206 \\
Site 4 & East & BW14/E1 & 2014 & 12.5 & 512706 & 340423 \\
& & BW14/E2 & 2014 & 13.5 & 512697 & 340404 \\
Site 5 & \multirow{2}{*}{ North } & BW14/N1 & 2014 & 11.5 & 512851 & 340215 \\
& & BW14/N2 & 2014 & 13.5 & 512809 & 340232 \\
\hline
\end{tabular}


Fig. 1 Locations of the 2011-2014 core sites together with those from earlier studies

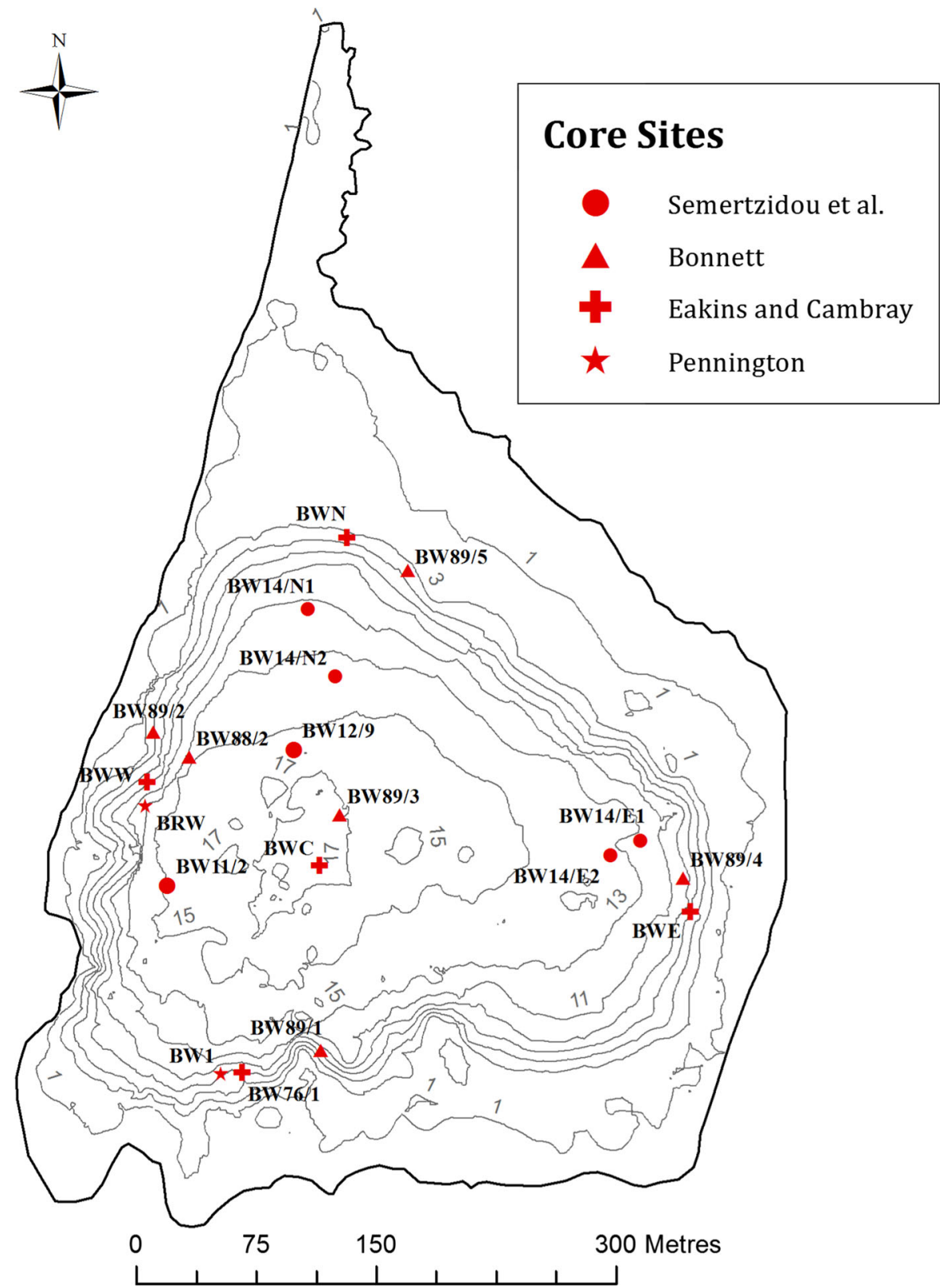

$661.7 \mathrm{keV}$ and $59.5 \mathrm{keV}$ respectively. The absolute efficiencies of the detectors were determined using calibrated sources and sediment samples of known activity. Corrections were made for the effect of selfabsorption of low energy $\gamma$-rays within the sample (Appleby et al. 1992), and for background radiation from the detectors themselves. Background counts of 60-h duration were carried out on each detector at regular intervals. Mean background count-rates were typically around $0.5 \mathrm{cph}$ (counts per hour) for the $46.5 \mathrm{keV}$ peak and $1 \mathrm{cph}$ for the $661.7 \mathrm{keV}$ peak.

X-ray fluorescence (XRF) analyses

Element analyses were conducted using a Bruker S2 ranger energy dispersive X-ray fluorescence (XRF) system, with XRF calibration and quality control based on a set of 14 certified reference materials including soil, sediment, rock and plant tissue. 
Samples were presented as homogenized loose powders pressed into sample cups lined with $6-\mu \mathrm{m}$ polypropylene film, measured under a helium atmosphere at three X-ray intensity settings and measurements were corrected for variable organic matter concentrations. Organic content data were derived either as loss-on-ignition (LOI, $105-550{ }^{\circ} \mathrm{C}$ ) or thermogravimetric mass loss $\left(150^{\circ}-530^{\circ} \mathrm{C}\right)$ under an $\mathrm{N}$ atmosphere (PerkinElmer STA6000).

\section{Results}

Fallout ${ }^{137} \mathrm{Cs}$ and ${ }^{210} \mathrm{~Pb}$ records for each study are given in the Electronic Supplementary Material, those for the present study in ESM1, those for the 1988/1989 cores in ESM2, and those for the 1976/1977 cores in ESM3.

Chronostratigraphic records

\section{${ }^{137}$ Cs records}

Figure 2 shows ${ }^{137} \mathrm{Cs}$ records in four cores from the western side of Brotherswater (Site 2), BRW collected in 1975, BW88/2 collected in 1988, BW89/1 collected in 1989, and BW11/2 collected in 2011. At the time of the 1975 study the only significant source of ${ }^{137} \mathrm{Cs}$ was fallout from the atmospheric testing of nuclear weapons. Fallout from this source, which began on a global scale following the first test of a thermonuclear device on 1 November 1952, reached a maximum value in 1963 before declining rapidly following the implementation of a global test ban treaty during that year. The ${ }^{137} \mathrm{Cs}$ record in BRW (Fig. 2a), has a distinct peak in the $4-5 \mathrm{~cm}$ sample that can reasonably be assumed to record the 1963 weapons fallout maximum. This implies a mean sediment accumulation rate during the 12-year period 1963-1975 that is similar to the value of $0.4 \pm 0.2 \mathrm{~cm} \mathrm{y}^{-1}$ inferred by Eakins et al. (1984) from the ${ }^{137} \mathrm{Cs}$ record in the nearby 1977 core BWW. The indistinct nature of the $1977{ }^{137} \mathrm{Cs}$ record (not shown here) suggests however that that core may have been taken from a disturbed site.

The 1988 core BW88/2, from a site around $30 \mathrm{~m}$ to the north-west of BWW in deeper water $(\sim 11 \mathrm{~m}$ compared to $7.5 \mathrm{~m})$, was collected just 2 years after the area had been impacted by fallout from the 1986 Chernobyl accident. The ${ }^{137} \mathrm{Cs}$ record in this core, shown in Fig. 3b, has two distinct peaks. The most a 1975

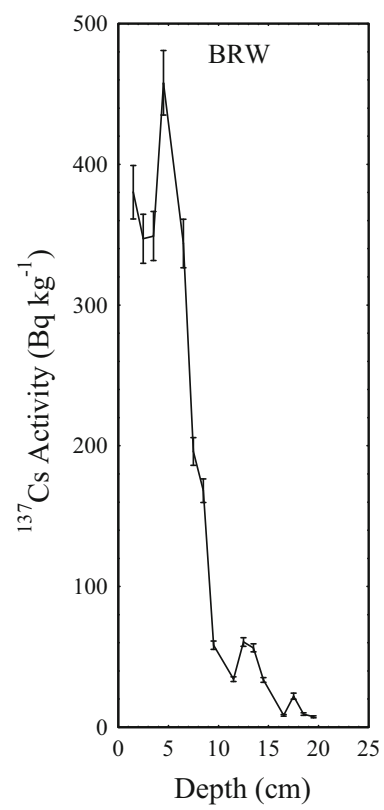

b 1988

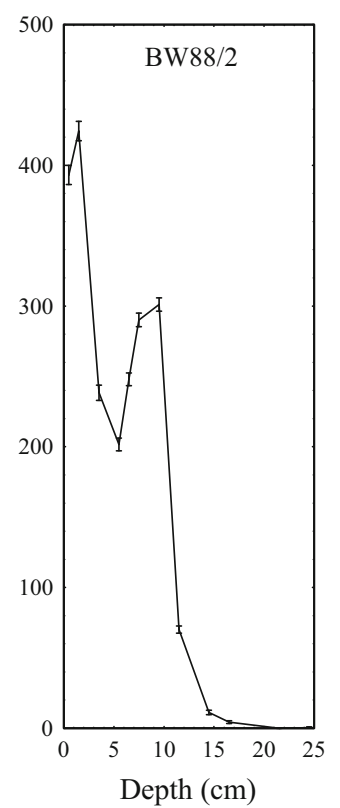

c 1989

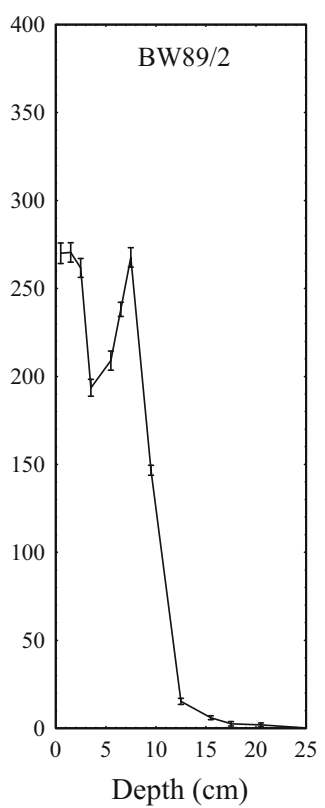

d 2011

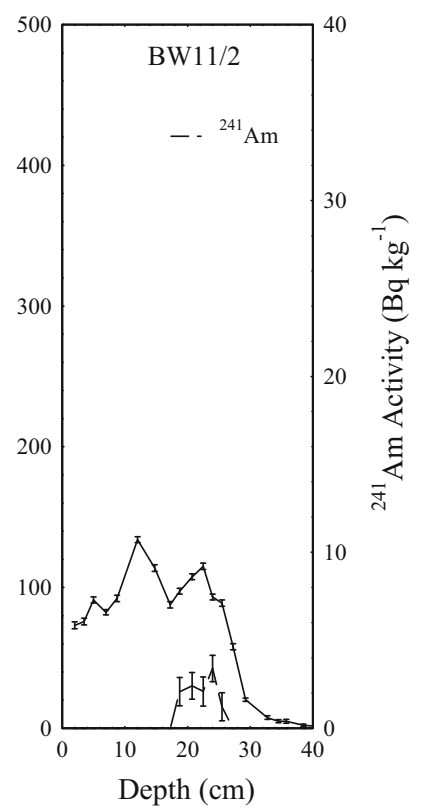

Fig. $2{ }^{137} \mathrm{Cs}$ records in cores from the western side of Brotherswater collected in a 1975; b 1988; c 1989; d 2011. Also shown is the ${ }^{241} \mathrm{Am}$ record in the 2011 core. The double ${ }^{137} \mathrm{Cs}$ peaks in the post-1986 cores record both the 1986 and 1963 fallout events 
Fig. $3{ }^{137} \mathrm{Cs}$ records in cores from the central area of Brotherswater collected in a 1977; b 1989; c 2012. Also shown is the ${ }^{241} \mathrm{Am}$ record in the 2012 core. The double ${ }^{137} \mathrm{Cs}$ peaks in the post-1986 cores record both the 1986 and 1963 fallout events

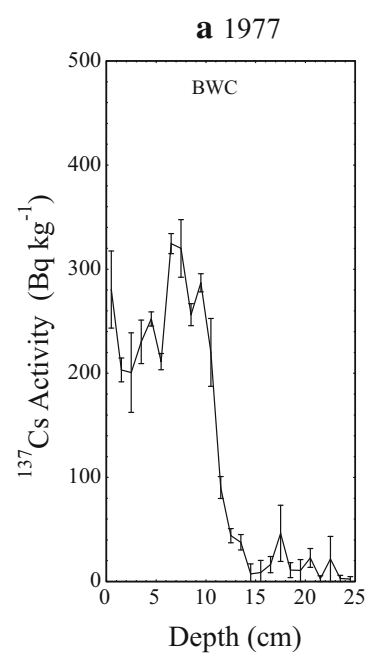

recent, in the $1-2 \mathrm{~cm}$ slice, records fallout from Chernobyl. This inference was supported by the presence at the same depth of traces of the short-lived Chernobyl isotope ${ }^{134} \mathrm{Cs}$ (half-life 2.2 years). The second older peak, between 7 and $10 \mathrm{~cm}$, is almost certainly a record of the 1963 nuclear weapons fallout maximum. Calculations show that $89 \%$ of the reduction of the concentration in the 1963 peak in the 1988 core compared to its value in the 1975 core is directly attributable to radioactive decay. The 1989 core (BW89/2), from $\sim 5 \mathrm{~m}$ water depth at a site around $30 \mathrm{~m}$ directly north of BWW, had a very similar record to the 1988 core, with high concentrations of Chernobyl ${ }^{137} \mathrm{Cs}$ in the uppermost $3 \mathrm{~cm}$ and a welldefined weapons ${ }^{137} \mathrm{Cs}$ peak in the $7-8 \mathrm{~cm}$ sample. Differences in detail are likely to be due, at least in part, to the sub-sampling procedure.

The 2011 core (BW11/2) was also from the western side of the lake but around $75 \mathrm{~m}$ nearer to the inlet stream in $15 \mathrm{~m}$ water depth. Both ${ }^{137} \mathrm{Cs}$ peaks are clearly visible (Fig. 3c) though at significantly greater depths due to progressive burial under more recent sediments. A small but distinct peak in ${ }^{241} \mathrm{Am}$ concentrations at the same depth shows that the older peak records the 1963 weapons fallout maximum (Appleby et al. 1991). Dilution by coarser sediments due to relative proximity to the input stream may account may account for the lower extent (68\%) to which the reduction in peak ${ }^{137} \mathrm{Cs}$ concentrations in the 2011 core compared to the $1988 / 1989$ cores is attributable to radioactive decay.
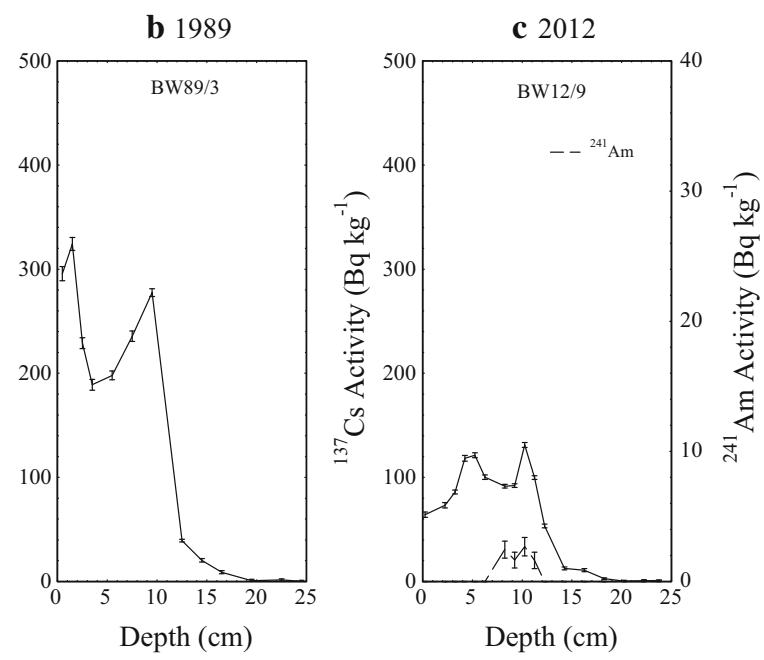

Similar results were obtained in cores from other parts of the lake where reductions in the 1963 and 1986 ${ }^{137} \mathrm{Cs}$ peaks attributable to radioactive decay were on average around $90 \%$. Figure 3 shows the effects of progressive burial and radioactive decay on ${ }^{137} \mathrm{Cs}$ records in three cores from the central area, the 1977 core (BWC), 1989 core (BW89/3) and 2012 core (BW12/9). Evidence that the deeper peak in the 2012 core records the 1963 weapons ${ }^{137} \mathrm{Cs}$ fallout maximum is again provided by the co-presence of traces of ${ }^{241} \mathrm{Am}$.

Records from the eastern side of the lake are shown in Fig. 4, and from the northern (outlet) end in Fig. 5. In both cases the 1977 records lack clarity compared to those from the 1989 cores. There also appears to have been a significant degradation of the ${ }^{137} \mathrm{Cs}$ records in the 2014 cores from the eastern side of the lake. Possible causes include slow diffusion of ${ }^{137} \mathrm{Cs}$ away from the peaks, localized sediment disturbances, or problems arising from sampling or instrumental procedures. Traces of ${ }^{241} \mathrm{Am}$ do however give some indication as to the 1963 depths in these cores. The 1986 and 1963 features do appear to be reasonably well preserved in the 2014 cores from the northern end of the lake.

\section{Mining Pb records}

The sediments of Brotherswater contain a record of pollution in the lake by lead mining in the catchment, an activity that has been carried out since at least the late seventeenth century. Figure 6 shows stable $\mathrm{Pb}$ 
a 1977

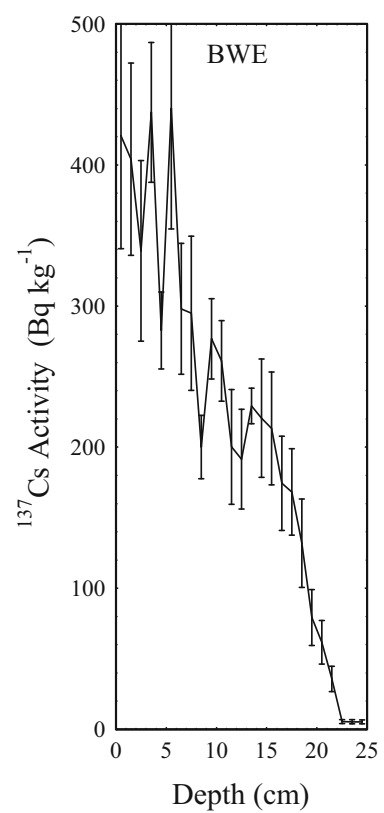

Fig. $4{ }^{137} \mathrm{Cs}$ records in cores from the eastern side of Brotherswater collected in a 1977; b 1989; c, d 2014. Also shown are the ${ }^{241} \mathrm{Am}$ records in the 2014 cores. The double c $2014 / 1$

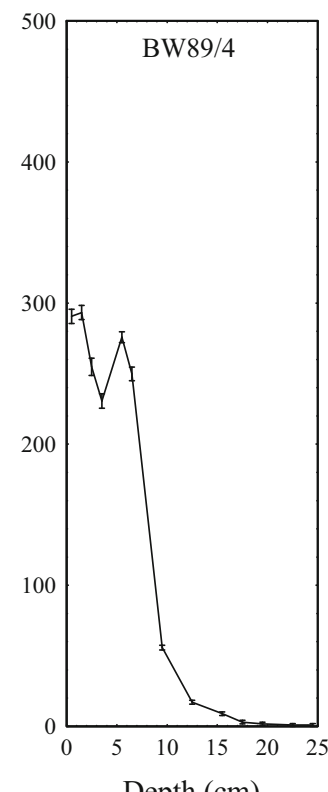

Depth $(\mathrm{cm})$

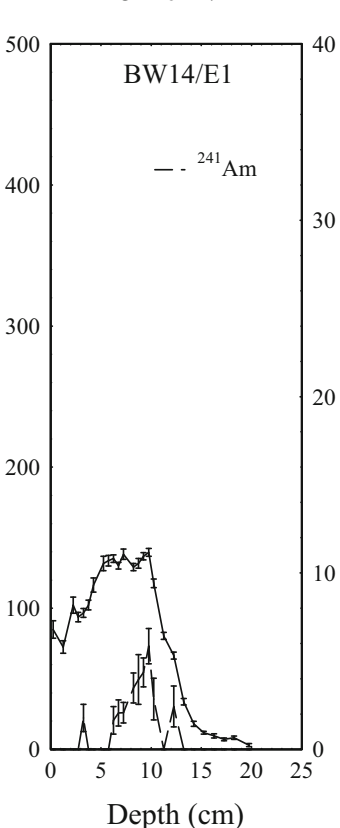

d $2014 / 2$

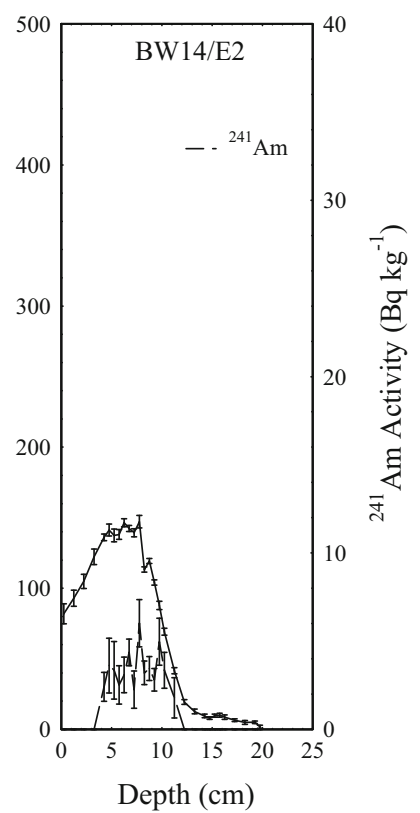

${ }^{137} \mathrm{Cs}$ peaks in the post- 1986 cores recording the 1986 and 1963 fallout events are less well resolved in the 2014 cores from this part of the lake

c $2014 / 1$

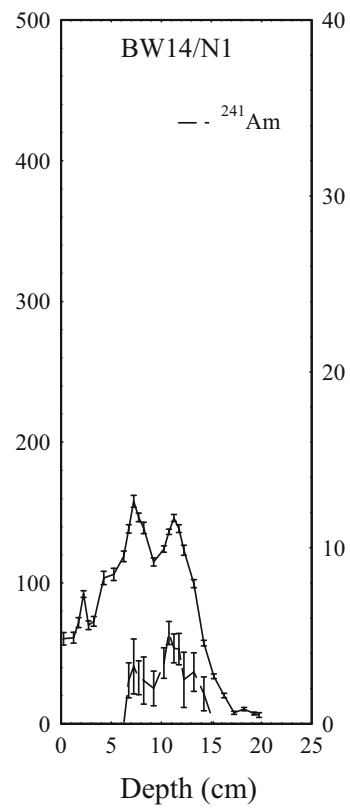

d $2014 / 2$

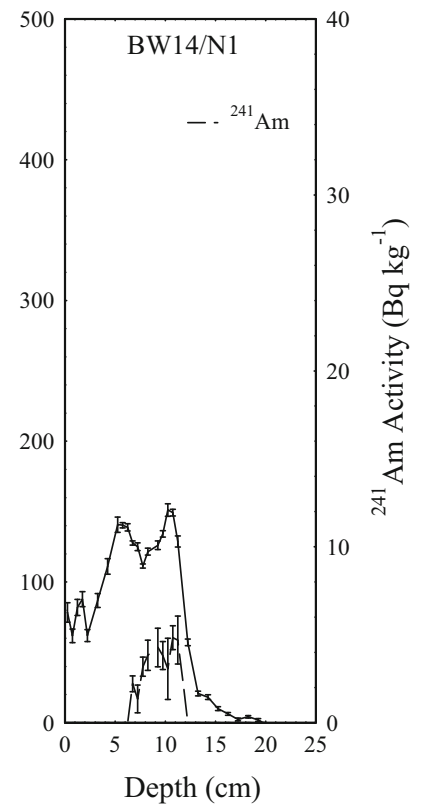

Fig. $5{ }^{137} \mathrm{Cs}$ records in cores from the northern (outlet) end of Brotherswater collected in a 1977; b 1989; c, d 2014. Also shown are the ${ }^{241} \mathrm{Am}$ records in the 2014 cores. The double ${ }^{137} \mathrm{Cs}$ peaks in the post-1986 cores record both the 1986 and 1963 fallout events 

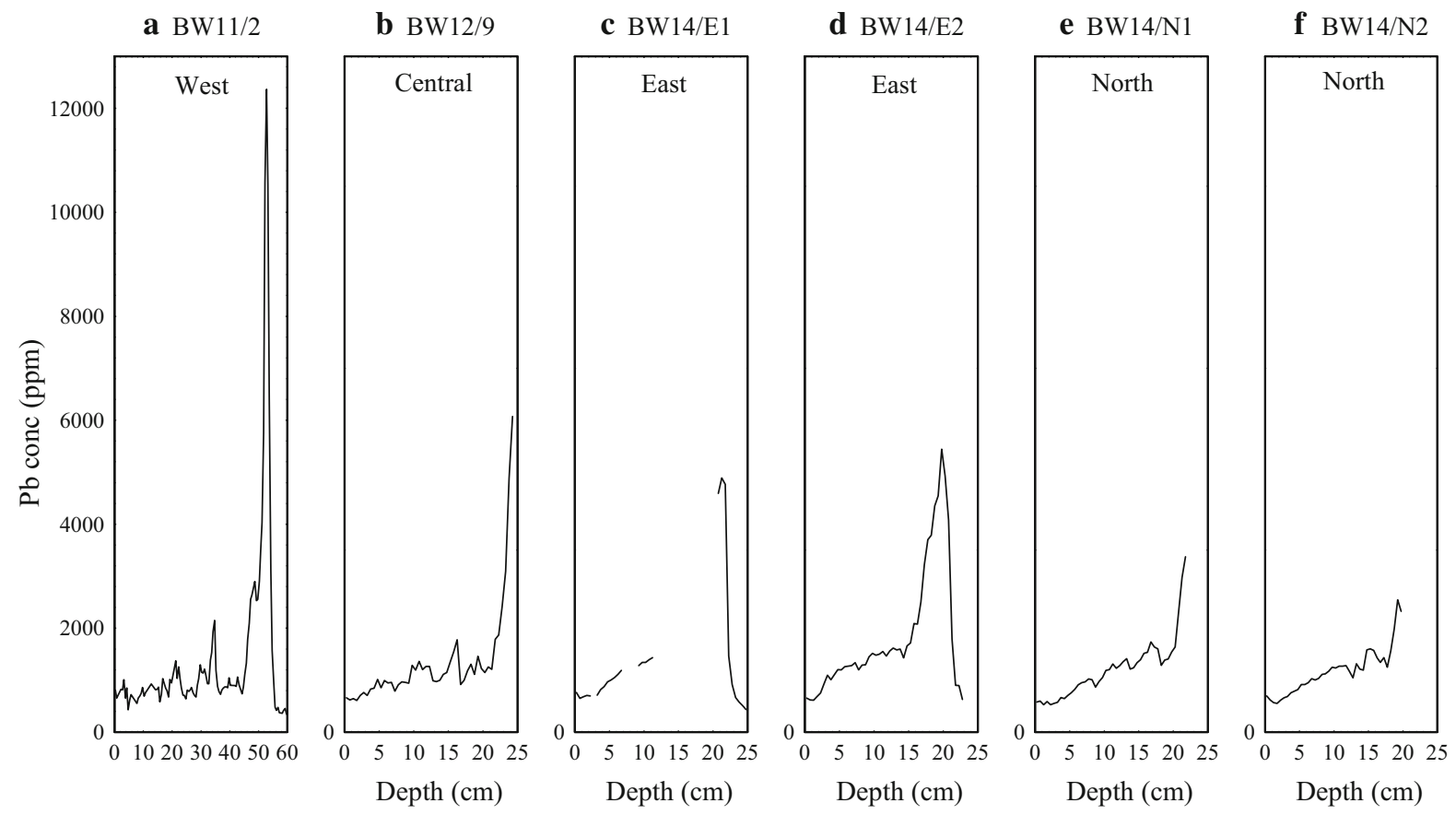

Fig. 6 Stable $\mathrm{Pb}$ records in the Brotherswater cores collected for the present study from $\mathbf{a}, \mathbf{b}$ the western; $\mathbf{c}, \mathbf{d}$ the eastern; e, $\mathbf{f}$ the northern areas of Brotherswater

records in cores BW11/2 and BW12/9 from the western and central parts of the lake (Schillereff et al. 2016), BW14/E1 and BW14/E2 from the eastern areas, and BW14/N1 and BW14/N from the northern areas. The most notable feature of these records is a clearly identifiable peak in $\mathrm{Pb}$ concentrations attributed to a very rapid, intense but short-lived increase in lead pollution associated with the introduction of water-powered milling at the Hartsop Hall mine during 1863-1871 (Schillereff et al. 2016). The depth at which this clearly identifiable chronostratigraphic feature occurs declines from a little over $50 \mathrm{~cm}$ in core BW11/2 to around $20 \mathrm{~cm}$ in the eastern and northern cores. This pattern, seen in more detail in Schillereff et al. (2016), shows that mean sedimentation rates in Brotherswater over the past 150 years are mainly controlled by distance from the main inflow, almost certainly due to the impact of inputs from the catchment. Maximum $\mathrm{Pb}$ concentrations vary from more than $12,000 \mathrm{ppm}$ in $\mathrm{BW} 11 / 2$ to less than $5000 \mathrm{ppm}$ at the more distant sites.

\section{Chronostratigraphic dates}

Table 4 summarises chronostratigraphic dates determined from the ${ }^{137} \mathrm{Cs}$ and stable $\mathrm{Pb}$ records for cores collected during 2011-2014. Sediments containing the mining $\mathrm{Pb}$ peak can reasonably be assumed to date from $1867 \pm 4$ years. The 1963 and 1986 dates are determined from the depths of peaks in the ${ }^{137} \mathrm{Cs}$ activity identified as recording the 1986 and 1963 peak fallout events. This assumes that time lags between the fallout record and sediment record are less than a year. Uncertainties in these dates can however arise from a number of causes. These include:

- Subsampling. Each core slice may include sediments from more than 1 year. Further, sediments from a given year may be spread over two or more slices.

- Fallout reaching the core site at any given time will include both direct inputs via atmospheric deposition onto the surface of the lake, and indirect inputs via transport from the catchment. The latter component may include significant amounts of fallout from earlier years. 
Table 4 Chronostratigraphic dates for the 2011-2014 cores compared with the corresponding depths determined from the raw CRS model ${ }^{210} \mathrm{~Pb}$ calculations

\begin{tabular}{|c|c|c|c|c|c|c|}
\hline \multirow[t]{3}{*}{ Location } & \multirow[t]{3}{*}{ Core } & \multicolumn{3}{|c|}{ From chronostratigraphic features } & \multicolumn{2}{|c|}{ From raw $\mathrm{CRS}{ }^{210} \mathrm{~Pb}$ calculations } \\
\hline & & \multicolumn{3}{|l|}{ Depth $(\mathrm{cm})$} & \multicolumn{2}{|l|}{ Depth $(\mathrm{cm})$} \\
\hline & & 1986 & 1963 & 1867 & 1986 & 1963 \\
\hline West & BW11/2 & $11.25-12.75$ & $21.75-23.25$ & $51.25-54.25$ & $11.25-11.65$ & $19.95-20.25$ \\
\hline Central & BW12/9 & $4.0-5.5$ & $9.75-10.75$ & $23.5-25.0$ & $5.25-5.45$ & $10.05-10.25$ \\
\hline \multirow[t]{2}{*}{ East } & BW14/E1 & $6.0-7.5$ & $9.25-10.25$ & $20.5-22.0$ & $6.45-6.65$ & $9.75-9.95$ \\
\hline & BW14/E2 & $4.75-6.25$ & $7.75-9.0$ & $19.25-20.75$ & $5.45-5.65$ & $9.25-9.45$ \\
\hline \multirow[t]{2}{*}{ North } & BW14/N1 & $6.75-7.75$ & $10.75-11.75$ & $21-22.5$ & $7.15-7.35$ & $12.05-12.25$ \\
\hline & $\mathrm{BW} 14 / \mathrm{N} 2$ & $5.0-6.5$ & $10-11$ & $19-20.5$ & $5.95-6.15$ & $10.45-10.65$ \\
\hline
\end{tabular}

Table 5 Chronostratigraphic dates for the 1988-1989 cores compared with the corresponding depths determined from the raw CRS model ${ }^{210} \mathrm{~Pb}$ calculations

\begin{tabular}{|c|c|c|c|c|c|}
\hline \multirow[t]{3}{*}{ Location } & \multirow[t]{3}{*}{ Core } & \multicolumn{2}{|c|}{ From chronostratigraphic features } & \multicolumn{2}{|c|}{ From raw CRS ${ }^{210} \mathrm{~Pb}$ calculations } \\
\hline & & \multicolumn{2}{|c|}{ Depth $(\mathrm{cm})$} & \multicolumn{2}{|l|}{ Depth $(\mathrm{cm})$} \\
\hline & & 1986 & 1963 & 1986 & 1963 \\
\hline \multirow[t]{2}{*}{ West } & BW88/2 & $1-2$ & $7.5-10$ & $0.75-1.25$ & $7.05-7.25$ \\
\hline & BW89/2 & $0.5-2.5$ & $7-8.5$ & $1.15-1.55$ & $7.45-7.65$ \\
\hline Central & BW89/3 & $1-2$ & $8.5-10.5$ & $1.55-1.85$ & $7.45-7.65$ \\
\hline East & BW89/4 & $0-2$ & $5-6.5$ & $0.95-1.25$ & $5.65-5.85$ \\
\hline North & BW89/5 & $0-1$ & $6-7.5$ & $0.95-1.35$ & $6.65-6.85$ \\
\hline
\end{tabular}

- Degradation of the sediment record by horizontal or vertical post-depositional transport, e.g. displacement by chemical migration, physical mixing of the surficial sediments, sediment focussing and slump events.

The results given in Table 4 reflect these uncertainties.

The 1988/1989 cores have just two chronostratigraphic dates, the 1963 nuclear weapons fallout maximum and the 1986 Chernobyl accident. These are shown in Table 5. Since these cores weren't analysed in the same detail and were sectioned more coarsely (1-cm intervals rather than $0.5-\mathrm{cm}$ intervals) the depths of sediments recording these events have a greater uncertainty. Further, the 1986 event is too recent to provide much information apart from demonstrating the integrity of the core.

The presence in many cores of significant ${ }^{137} \mathrm{Cs}$ concentration at depths well below the expected 1952 depth precluded use of the ${ }^{137} \mathrm{Cs}$ fallout onset date as a reliable chronostratigraphic marker.

${ }^{210} \mathrm{~Pb}$ records

The ${ }^{210} \mathrm{~Pb}$ concentration in sediment samples deposited on the bed of a lake has two components, a supported component derived from the in situ decay of ${ }^{226} \mathrm{Ra}$ contained within the sample, and an unsupported component derived principally from atmospheric fallout of ${ }^{210} \mathrm{~Pb}$ onto the lake and its catchment. In all of the Brotherswater cores, total ${ }^{210} \mathrm{~Pb}$ declined with depth to values determined to be in equilibrium with the supporting ${ }^{226} \mathrm{Ra}$ and there was no evidence of significant inputs from other sources such as submarine groundwater discharge. The supported component is essentially constant over timescales relevant to ${ }^{210} \mathrm{~Pb}$ dating and is determined by measuring the activity of the parent radionuclide 
${ }^{226} \mathrm{Ra}$. The unsupported (or fallout) component is determined by subtracting the measured supported activity from the measured total ${ }^{210} \mathrm{~Pb}$ activity. Measured values of the ${ }^{226} \mathrm{Ra}$ (supported ${ }^{210} \mathrm{~Pb}$ ) activity in the Brotherswater sediments were relatively uniform over the bed of the lake, with a mean value of $38 \pm 3 \mathrm{~Bq} \mathrm{~kg}^{-1}$.

The supply of fallout ${ }^{210} \mathrm{~Pb}$ to lake sediments can include both direct atmospheric inputs onto the surface of the lake itself and indirect inputs deposited onto the catchment and then transported to the lake by runoff or erosion. The distribution of ${ }^{210} \mathrm{~Pb}$ over the bed of the lake can be affected both by the pattern of sedimentation and post-depositional transport processes such as sediment slumps from the margins of the lake. The initial concentrations $C_{\mathrm{o}}(t)\left(\mathrm{Bq} \mathrm{kg}^{-1}\right)$ in sediments presently of age $t$ are governed by the equation

$C_{0}(t)=\frac{P(t)}{r(t)}$

where $P(t), r(t)$ are the rates of supply of ${ }^{210} \mathrm{~Pb}$ $\left(\mathrm{Bq} \mathrm{m}^{-2} \mathrm{y}^{-1}\right)$ and sediment $\left(\mathrm{kg} \mathrm{m}^{-2} \mathrm{y}^{-1}\right)$ at the time those sediments were laid down. These will diminish over time, principally by the effects of radioactive decay but possibly also by other causes such as physical mixing of the near surface sediments or chemical diffusion within the pore waters (cf. Smith 2001). Where radioactive decay is dominant the present concentration in sediments of depth $z$ and age $t$ will be

$C(z)=\frac{P(t)}{r(t)} \mathrm{e}^{-\lambda t}$.

This equation shows that although the decline in ${ }^{210} \mathrm{~Pb}$ activity with depth in a core is likely to be dominated by exponential decay, deviations from a simple exponential function may occur due to variations in the initial activity caused by changes in the rates of supply of ${ }^{210} \mathrm{~Pb}$ and/or sediment at the core site.

Table 6 summarises a number of key parameters associated with each core including

- the measured unsupported ${ }^{210} \mathrm{~Pb}$ activity in the surficial sediments of each core,

- the unsupported inventory calculated by numerical integration of the activity versus depth record:

$$
A_{0}=\int_{0}^{m_{\text {equ }}} C(z(m)) \mathrm{d} m
$$

where $m$ is depth in the core measured in terms of cumulative dry mass $\left(\mathrm{g} \mathrm{cm}^{-2}\right)$ and $m_{\text {equ }}$ the ${ }^{210} \mathrm{~Pb}$ equilibrium depth, and

- the mean ${ }^{210} \mathrm{~Pb}$ supply rate required to sustain the inventory, calculated using the formula

$$
P=\lambda A_{0} \text {. }
$$

Estimates of the mean annual atmospheric flux of ${ }^{210} \mathrm{~Pb}$ at Brotherswater, determined both from direct fallout measurements (Eakins et al. 1984) corrected for mean annual rainfall $\left(2609 \mathrm{~mm} \mathrm{y}^{-1}\right)$, and soil core inventories collected from flat sites adjacent to the lake (Semertzidou 2018), ranged from $177-188 \mathrm{~Bq} \mathrm{~m}^{-2} \mathrm{y}^{-1}$ with a mean value of $183 \mathrm{~Bq} \mathrm{~m}^{-2} \mathrm{y}^{-1}$. At eight sites, mainly in the northern and eastern areas of the lake remote from the main inflow, the ${ }^{210} \mathrm{~Pb}$ supply rates are close to the atmospheric flux. Much higher values at sites near the inflow clearly include significant inputs from the catchment. Anomalously high values in the 1977 cores BWE (near the eastern shore) and BWN (northern area), both of which are far from the inlet stream, are most probably due to reworked inputs of sediment from the margins of the lake. Generally higher surface concentrations in sediments from the northern and eastern areas are presumably due to the fact that only the finer components of allochthonous inputs from the catchment will travel that far.

Figure 7 compares unsupported ${ }^{210} \mathrm{~Pb}$ activity versus depth records in cores from the western side of Brotherswater collected in 1977, 1988, 1989 and 2011. To eliminate the influence of compaction the results have been plotted against depth as cumulative dry mass. The 1977 and 1988/1989 cores have very similar surficial concentrations, with a mean value of $393 \mathrm{~Bq} \mathrm{~kg}^{-1}$. A significantly lower surficial concentration was recorded in the 2011 core $\left(286 \mathrm{~Bq} \mathrm{~kg}^{-1}\right)$, possibly due to changes that have taken place over the past two decades. When corrected for radioactive decay, sediments in this core dating from the late 1980s have a concentration similar to that in the surficial sediments of BW88/2. There do however appear to have been significant variations in the overall sedimentation rates at these sites, mainly controlled (as suggested above) by distance from the 
Table 6 Fallout ${ }^{210} \mathrm{~Pb}$ parameters for the Brotherswater cores

\begin{tabular}{|c|c|c|c|}
\hline \multirow[t]{2}{*}{ Core and date } & \multicolumn{3}{|c|}{ Unsupported ${ }^{210} \mathrm{~Pb}$} \\
\hline & $\begin{array}{l}\text { Surface activity } \\
\mathrm{Bq} \mathrm{kg}^{-1}\end{array}$ & $\begin{array}{l}\text { Inventory } \\
\mathrm{Bq} \mathrm{m}^{-2}\end{array}$ & $\begin{array}{l}\text { Mean supply rate } \\
\mathrm{Bq} \mathrm{m}^{-2} \mathrm{y}^{-1}\end{array}$ \\
\hline \multicolumn{4}{|l|}{ Western } \\
\hline BWW (1977) & 374 & 9990 & 311 \\
\hline BW88/2 (1988) & 409 & 7998 & 249 \\
\hline BW89/2 (1989 & 396 & 6298 & 196 \\
\hline BW11/2 (2011) & 286 & 19,450 & 606 \\
\hline \multicolumn{4}{|l|}{ Central } \\
\hline BWC (1977) & 387 & 7772 & 242 \\
\hline BW89/3 (1989) & 412 & 7195 & 224 \\
\hline BW12/9 (2012) & 346 & 5542 & 173 \\
\hline \multicolumn{4}{|l|}{ Northern } \\
\hline BWN (1977) & 381 & 15,354 & 478 \\
\hline BW89/5 (1989) & 394 & 6507 & 203 \\
\hline BW14/N1 (2014) & 425 & 6884 & 214 \\
\hline BW14/N2 (2014) & 506 & 5606 & 175 \\
\hline \multicolumn{4}{|l|}{ Eastern } \\
\hline BWE (1977) & 546 & 10,360 & 323 \\
\hline BW89/4 (1989) & 452 & 6222 & 194 \\
\hline BW14/E1 (2014) & 579 & 6048 & 188 \\
\hline BW14/E2 (2014) & 549 & 4634 & 144 \\
\hline
\end{tabular}

a 1977

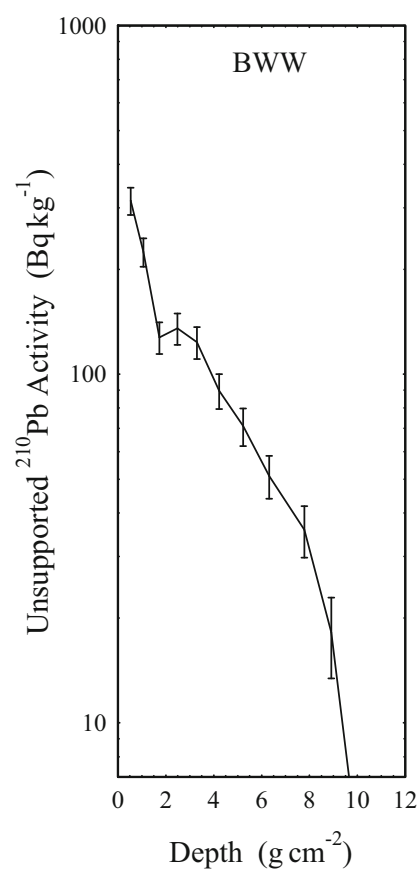

b 1988

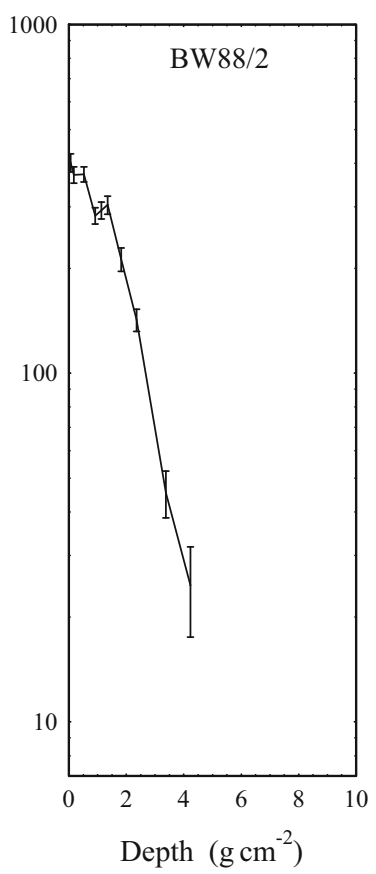

c 1989

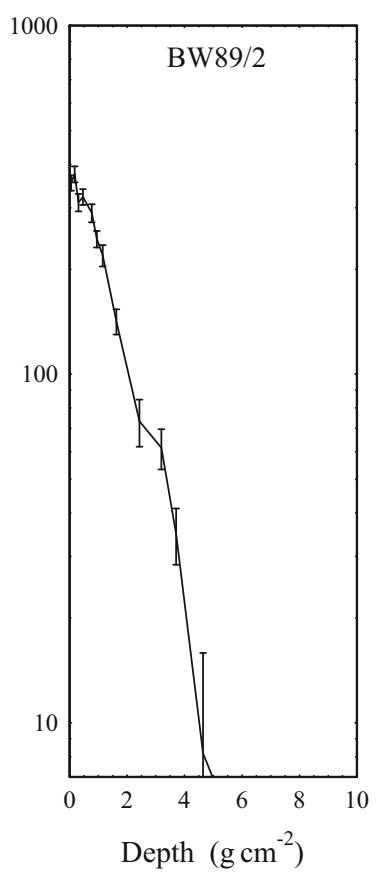

d 2011

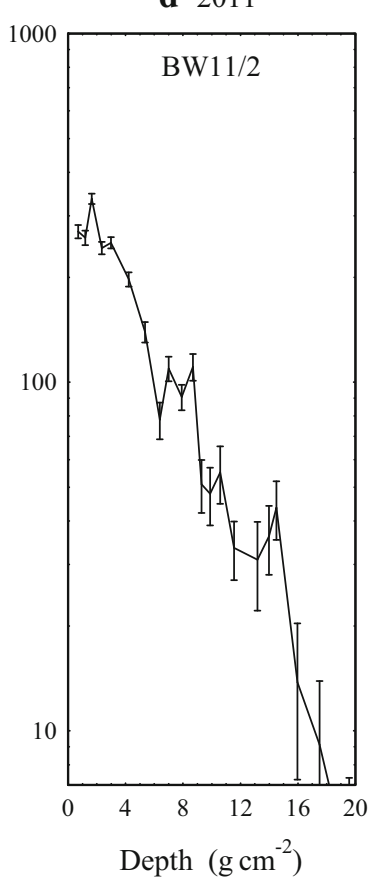

Fig. $7{ }^{210} \mathrm{~Pb}$ records in four cores from the western side of Brotherswater collected in a 1977; b 1988; c 1989; d 2011 
main inlet stream. Defining the ${ }^{210} \mathrm{~Pb}$ dating horizon as the point at which unsupported ${ }^{210} \mathrm{~Pb}$ activity declines to values close to the limit of detection, typically around $6{ }^{210} \mathrm{~Pb}$ half-lives ( $\sim 130$ years $)$, the depth at which this is reached declines from $45 \mathrm{~cm}$ $\left(19 \mathrm{~g} \mathrm{~cm}^{-2}\right)$ in BW11/2 closest to the inflow to around $20 \mathrm{~cm}\left(6 \mathrm{~g} \mathrm{~cm}^{-2}\right)$ in BW88/2 and BW89/2 further away. In spite of having very different water depths (11 $\mathrm{m}$ and $5 \mathrm{~m}$ respectively), the latter two cores have very similar ${ }^{210} \mathrm{~Pb} /{ }^{226} \mathrm{Ra}$ equilibrium depths Deviations from a simple exponential decline are somewhat more pronounced in the 2011 core though this may in part be due to better resolution as a result of being sampled at $0.5-\mathrm{cm}$ intervals compared to 1 -cm intervals for the $1988 / 1989$ cores.

Unsupported ${ }^{210} \mathrm{~Pb}$ records in cores from the central area of Brotherswater, are broadly similar (Fig. 8) in spite of being collected by three different groups over a period of 35 years. Although there are again a number of small irregularities that may reflect minor short time-scale differences over small spatial scales, these cores have similar surface concentrations and the ${ }^{210} \mathrm{~Pb}$ dating horizons lie at similar depths $(23-26 \mathrm{~cm}$ or 5.6-6.5 $\mathrm{g} \mathrm{cm}^{-2} \mathrm{y}^{-1}$ ). Their records are also similar to those in the $1988 / 1989$ cores located in more northerly locations on the western side of the lake less impacted by stream inputs from the catchment.

Figure 9 compares unsupported ${ }^{210} \mathrm{~Pb}$ records in cores from the eastern side of the lake collected in
1977, 1989 and 2014. Concentrations in the surficial sediments of these cores range from 452 to $579 \mathrm{~Bq} \mathrm{~kg}^{-1}$ with a mean value of $532 \mathrm{~Bq} \mathrm{~kg}^{-1}$, significantly higher than in cores from the western and central areas of the lake. The 1989 and 2014 cores also had significantly lower overall sedimentation rates as measured by the depths of the ${ }^{210} \mathrm{~Pb}$ dating horizon; in all three cores these were between 18 and $19 \mathrm{~cm}$ (3.5-4.25 $\left.\mathrm{g} \mathrm{cm}^{-2}\right)$. A higher sedimentation rate at the site of the 1977 core, indicated by the significantly deeper record, may be due to remobilisation of sediment from the margins of the lake. This core was from $7.5 \mathrm{~m}$ water depth compared to $\sim 9 \mathrm{~m}$ for the 1989 core and more than $11 \mathrm{~m}$ for the 2014 cores. The 2014/2 core appears to have two small but significant irregularities, one at the middle of the record and the other near the base.

Figure 10 shows records from a similar suite of cores from the northern part of the lake. Surface concentrations in these cores have a mean value (427 $\mathrm{Bq} \mathrm{kg}^{-1}$ ) intermediate between those from the western and central areas of the lake, and those from the eastern areas. The depths of the ${ }^{210} \mathrm{~Pb}$ dating horizon in the 1989 and 2014 cores are similar to though slightly greater than those in the corresponding cores from the eastern area. A significantly higher sedimentation rate in the 1977 core (from $4 \mathrm{~m}$ water depth) may again be due to remobilisation of sediment from the margins of the lake.
Fig. $8{ }^{210} \mathrm{~Pb}$ records in three cores from the central area of Brotherswater collected in a 1977; b 1989; c 2012

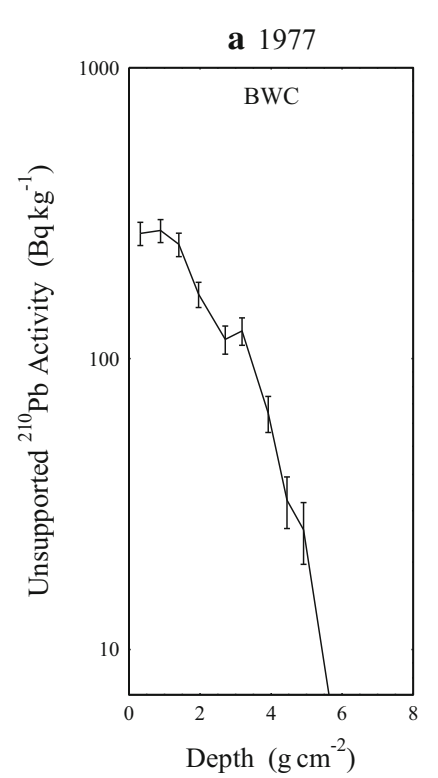

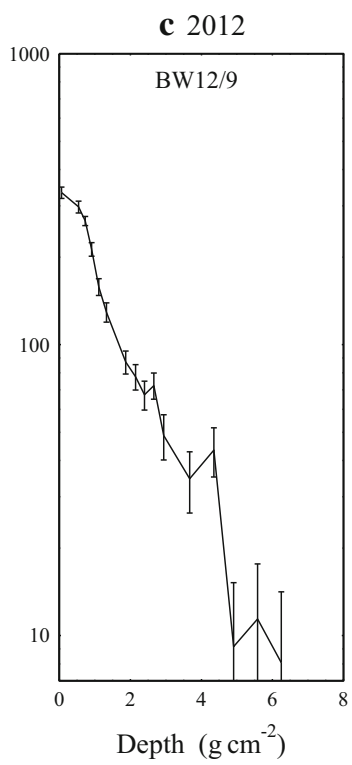



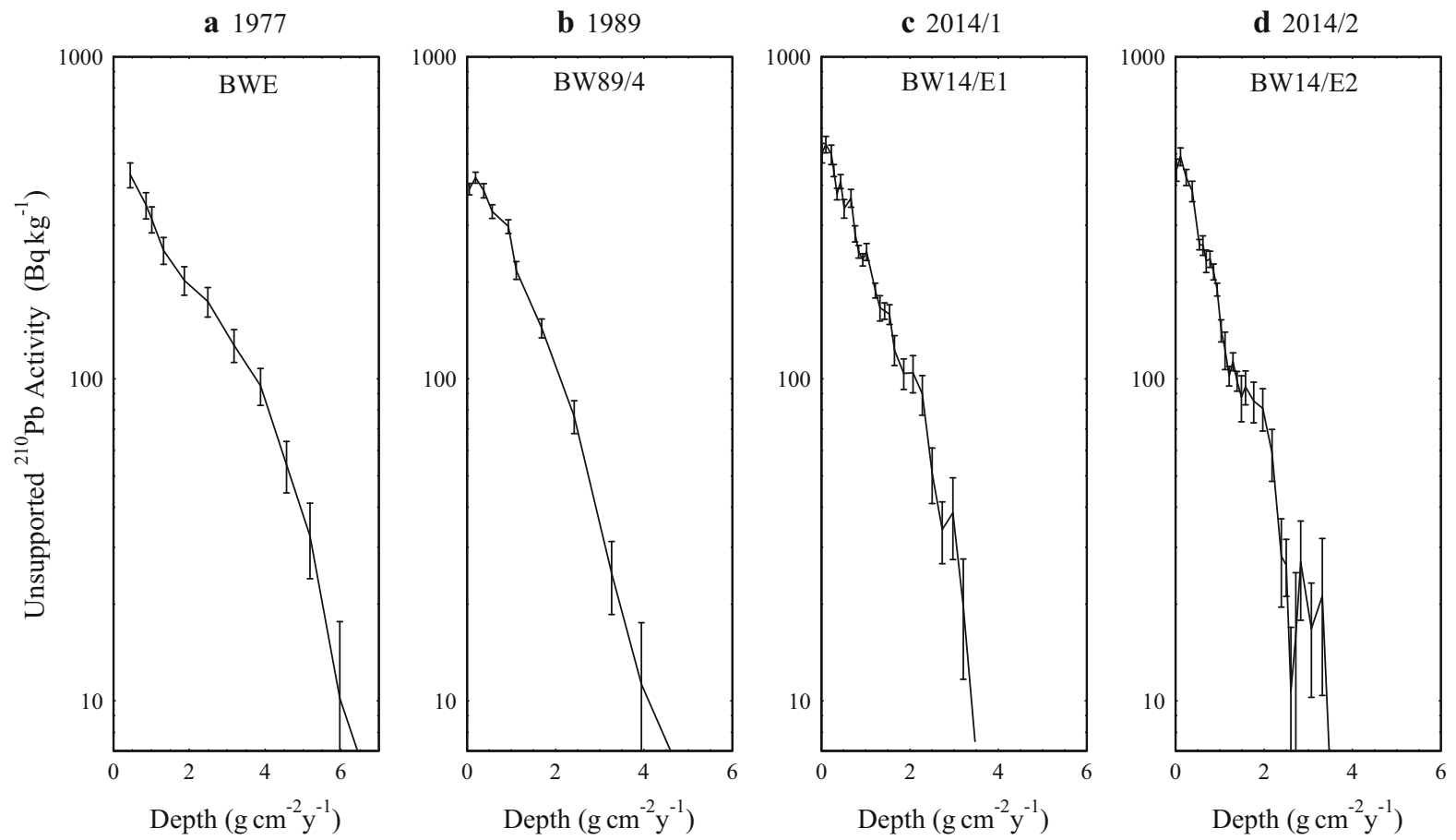

Fig. $9{ }^{210} \mathrm{~Pb}$ records in cores from the eastern side of Brotherswater collected in a 1977; b 1989; c, d 2014
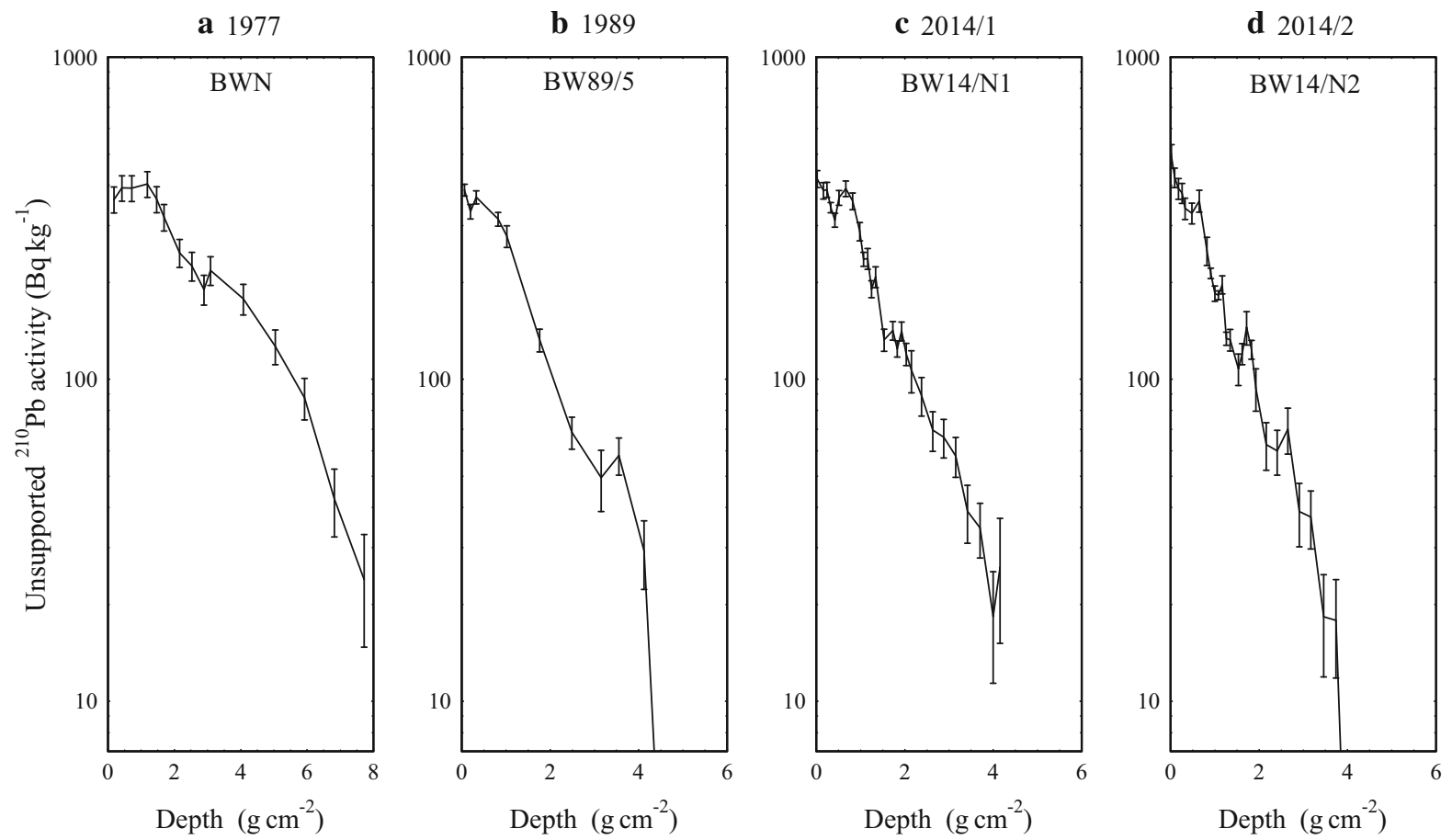

Fig. $10{ }^{210} \mathrm{~Pb}$ records in cores from the northern end of Brotherswater collected in a 1977; b 1989; c, d 2014 
${ }^{210} \mathrm{~Pb}$ dates and sedimentation rates

Most calculations of ${ }^{210} \mathrm{~Pb}$ dates assume that the measured present-day concentration $C(t)$ in sediments of age $t$ is related to the original concentration $C_{0}(t)$ by the radioactive decay law

$C(t)=C_{0}(t) \mathrm{e}^{-\lambda t}$

where $\lambda$ the ${ }^{210} \mathrm{~Pb}$ radioactive decay constant. In order to calculate the age $t$ it is first necessary to estimate the initial concentration $C_{0}(t)$. The two most common models used for making this estimate (Appleby and Oldfield 1978; Robbins 1978) are:

1. The CIC (Constant Initial Concentration model), which assumes that the initial concentration has a constant value $C_{0}$.

2. The CRS (Constant Rate of ${ }^{210} \mathrm{~Pb}$ Supply), which assumes that the initial concentration is governed by a constant rate of supply of fallout ${ }^{210} \mathrm{~Pb}$ to the core site.

These assumptions greatly simplify the complexity of the processes by which fallout ${ }^{210} \mathrm{~Pb}$ accumulates in lake sediments. Here we use the well-established chrono-stratigraphic dates determined from the ${ }^{137} \mathrm{Cs}$ and mining $\mathrm{Pb}$ records to investigate the reliability of ${ }^{210} \mathrm{~Pb}$ as a dating tool, and in particular the extent to which either of the above assumptions provides a reasonably accurate approximation to the actual processes by which ${ }^{210} \mathrm{~Pb}$ records are formed. Any discrepancies between raw dates calculated using either of the above simple models will be due to deviations of the actual processes from the model assumptions. The raw dates may however be corrected by applying the models in a piecewise way using the methods described in Appleby (2001). Using the results from all three studies, comparisons are made not only between records from different parts of the lake but also between records from different times.

\section{Comparison between ${ }^{210} \mathrm{~Pb}$ and chronostratigraphic dates}

Tables 4 and 5 also compare the 1986 and 1963 depths determined from the 1986 and $1963{ }^{137} \mathrm{Cs} /{ }^{241} \mathrm{Am}$ records with the corresponding depths determined from the raw CRS model ${ }^{210} \mathrm{~Pb}$ dates calculated by assuming a constant ${ }^{210} \mathrm{~Pb}$ supply rate over the entire
${ }^{210} \mathrm{~Pb}$ timespan. In most cases there was a relatively good level of agreement. Cores showing a high level of agreement were mainly from sites distant from the main inlet and included BW89/2 (western side of lake), BW12/9 (central area), BW14/E1, BW14/E2, BW89/4 (eastern side), and BW14/N2, BW89/5 (northern end). At all these sites the ${ }^{210} \mathrm{~Pb}$ supply rate appears to have been relatively constant and comparable to the atmospheric flux. Values ranged from 144 to $203 \mathrm{~Bq} \mathrm{~m}^{-2} \mathrm{y}^{-1}$, with a mean value of $180 \mathrm{~Bq} \mathrm{~m}^{-2} \mathrm{y}^{-1}$.

Sites where there were significant discrepancies between the ${ }^{210} \mathrm{~Pb}$ and ${ }^{137} \mathrm{Cs}$ dates all had ${ }^{210} \mathrm{~Pb}$ supply rates that significantly exceeded the atmospheric flux. They included BW11/2, BW88/2 (western side), BW89/3 (central) and BW14/N1 (northern). At BW11/2 the ${ }^{210} \mathrm{~Pb}$ calculations placed 1963 at a depth of $20 \mathrm{~cm}, 2.5 \mathrm{~cm}$ above the 1963 depth determined from the ${ }^{137} \mathrm{Cs}$ record. The very high ${ }^{210} \mathrm{~Pb}$ supply rate to this core (mean value $606 \mathrm{~Bq} \mathrm{~m}^{-2} \mathrm{y}^{-1}$ ) can be attributed to substantial inputs of catchment ${ }^{210} \mathrm{~Pb}$ via the main inlet stream, evidenced by the mining $\mathrm{Pb}$ pollution records. Calculations using the ${ }^{137} \mathrm{Cs}$ dates as reference points show the cause of the dating discrepancy to be a substantial increase in inputs of ${ }^{210} \mathrm{~Pb}$ in recent decades. $\mathrm{Net}^{210} \mathrm{~Pb}$ supply rates have risen from $482 \mathrm{~Bq} \mathrm{~m}^{-2} \mathrm{y}^{-1}$ before 1963 to a post-1963 value of $648 \mathrm{~Bq} \mathrm{~m}^{-2} \mathrm{y}^{-1}$. Although less impacted by catchment inputs, there were similar increases at BW88/2 and $\mathrm{BW} 89 / 3$. At both these sites the ${ }^{210} \mathrm{~Pb}$ supply rates increased from pre-1963 values comparable to the atmospheric flux to post-1963 values of between 270 and $295 \mathrm{~Bq} \mathrm{~m}^{-2} \mathrm{y}^{-1}$.

At the northerly site BW14/N1 the ${ }^{210} \mathrm{~Pb} 1963$ depth was $1 \mathrm{~cm}$ below the weapons ${ }^{137} \mathrm{Cs}$ peak. In this case the discrepancy appears to have been caused by a reduction in the ${ }^{210} \mathrm{~Pb}$ supply rate, from $230 \mathrm{~Bq} \mathrm{~m}^{-2}$ $\mathrm{y}^{-1}$ before 1963 to a near atmospheric value $\left(180 \mathrm{~Bq} \mathrm{~m}^{-2} \mathrm{y}^{-1}\right)$ during 1963-1986.

In the 2011-2014 cores, additional nineteenth century chronostratigraphic information was provided by the stable $\mathrm{Pb}$ records. The ${ }^{210} \mathrm{~Pb}$ dating horizon for these cores, measured by a $99 \%$ reduction in activity (corresponding to 148 years accumulation), lies between 1863 and 1866 . This coincides almost exactly with the 1863-1871 period of intensive mining linked to the episodes of $\mathrm{Pb}$ pollution seen in the sediment records. Although calculations of the $99 \%$ equilibrium depths have a degree of uncertainty, at most sites they 
were relatively close to the depth of the $\mathrm{Pb}$ concentration peak. This provides independent evidence of the origin of the $\mathrm{Pb}$ peaks and supports their use as reliable chronostratigraphic markers.

In the 1977 cores, the ${ }^{137} \mathrm{Cs}$ records were too indistinct and 1963 too recent to make reliable comparisons between the ${ }^{210} \mathrm{~Pb}$ and ${ }^{137} \mathrm{Cs}$ dates. ${ }^{210} \mathrm{~Pb}$ dates for these cores, particularly those with high ${ }^{210} \mathrm{~Pb}$ supply rates, need to be regarded with some caution.

\section{Sedimentation rate records}

At those sites were there were discrepancies between the raw ${ }^{210} \mathrm{~Pb}$ dates and well-established chronological markers, corrections to the ${ }^{210} \mathrm{~Pb}$ dates were calculated by applying the CRS model in a piecewise way. Detailed results including sedimentation rates versus time are given in the Electronic Supplementary Material ESM4 (present study), ESM5, (1988/1989 cores) and ESM6 (1976/1977 cores). Although there are differences in detail, a number of broad features do emerge.

- At most sites sedimentation rates were relatively constant during the first half of the twentieth century but did show significant increases during the second half of the century.

- The largest increases were at sites along the western side of the lake nearer the main inlet, mainly driven by erosive inputs from the catchment and associated with substantial inputs of allochthonous fallout ${ }^{210} \mathrm{~Pb}$.

- The increases were relatively modest at sites in the central, eastern and northern areas of the lake, away from the main inlet. The supply of ${ }^{210} \mathrm{~Pb}$ to these sites was dominated by the direct atmospheric flux.

Although the mean pre-1963, 1963-1986 and post1986 sedimentation rates determined from the ${ }^{210} \mathrm{~Pb}$ records will be similar to those determined from the chronostratigraphic dates, the ${ }^{210} \mathrm{~Pb}$ calculations do give more detail as to the timing of any changes. Results for cores from the western side of the lake, shown in Fig. 11a, highlight dramatic differences between cores separated by less than $100 \mathrm{~m}$. The mean pre-1950 sedimentation rate at BW11/2 $\left(0.14 \mathrm{~g} \mathrm{~cm}^{-2} \mathrm{y}^{-1}\right)$ is 4 times higher than at BW88/2 and $\quad$ BW89/2 $\quad\left(0.032 \mathrm{~g} \mathrm{~cm}^{-2} \mathrm{y}^{-1} \quad\right.$ and $\mathbf{a}$
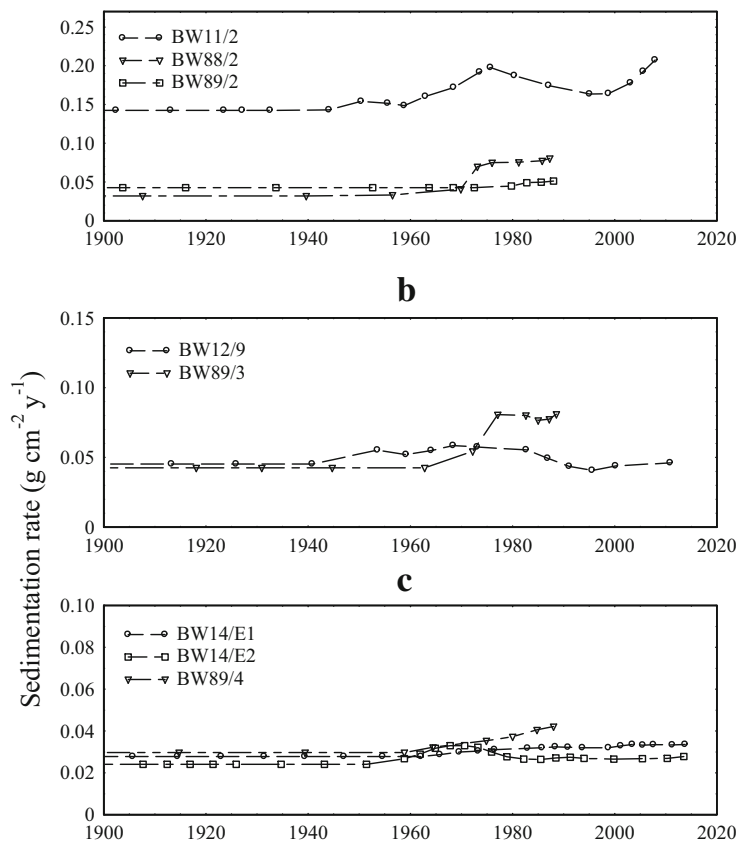

d

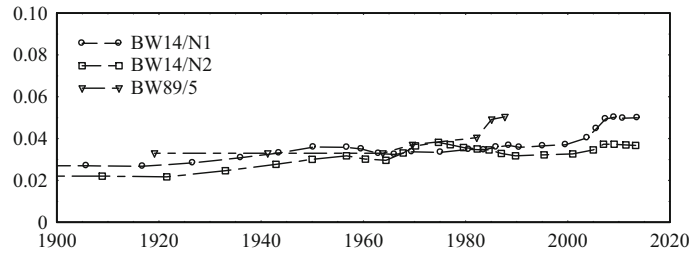

Fig. 11 Sedimentation rates versus time in cores from a the western; b central; c eastern; d northern areas of Brotherswater

$0.043 \mathrm{~g} \mathrm{~cm}^{-2} \mathrm{y}^{-1}$ respectively). The post-1950 increases at BW11/2, evidenced by the ${ }^{137}$ Cs record, began late 1950s or early 1960s and reached a maximum value in the mid-1970s. As indicated above, the cause of the high sedimentation rates at BW11/2 is almost certainly allochthonous inputs due to its relative proximity to the main inlet stream. The results given in Schillereff et al. (2016) show a clear gradient, with even higher sedimentation rates (based on the depth of the mid-nineteenth century $\mathrm{Pb}$ pollution event) at sites even closer to the inlet stream. Increased catchment inputs driving these changes appear to have had a smaller but still significant impact at BW88/2. The ${ }^{137} \mathrm{Cs}$ record shows that the mean post-1963 sedimentation rate at this site is twice as high as the pre-1950 value. Although the raw CRS model ${ }^{210} \mathrm{~Pb}$ calculations (assuming a constant supply rate) also indicate a recent increase in the sedimentation rate, the 
${ }^{137} \mathrm{Cs}$ dates show that these calculations underestimate the magnitude of this change. The corrected ${ }^{210} \mathrm{~Pb}$ results date the increase to around 1970 and suggest that it was relatively abrupt. A corresponding increase in the ${ }^{210} \mathrm{~Pb}$ supply rate may indicate that the increase was due to sediment remobilization and downslope transport from the western margins. This core was from $11 \mathrm{~m}$ water depth, near the base of the slope. The more marginal core BW89/2 (5 m water depth) appears to have experienced little impact. The results for this site indicate no more than a relatively minor increase in the 1980s.

The central cores BW12/9 and BW89/3 had very similar pre-1950 sedimentation rates $\left(0.047 \mathrm{~g} \mathrm{~cm}^{-2}\right.$ $\mathrm{y}^{-1}$ and $0.042 \mathrm{~g} \mathrm{~cm}^{-2} \mathrm{y}^{-1}$ respectively), as shown in Fig. 11b. At BW12/9 there was an episode of increased sedimentation (independently supported by the ${ }^{137} \mathrm{Cs}$ dates) lasting from the 1950 s through to the 1980s. This appears to have been a relatively localized event. At BW89/3 sedimentation rates remain relatively constant until around 1970 when there were abrupt increases in both the sediment and ${ }^{210} \mathrm{~Pb}$ supply rates similar to those at $\mathrm{BW} 88 / 2$.

The eastern cores BW14/E1, BW14/E2 and BW89/ 4 also had very similar pre-1950 sedimentation rates, though significantly lower than in the central area. Mean values were $0.029 \mathrm{~g} \mathrm{~cm}^{-2} \mathrm{y}^{-1}, 0.024 \mathrm{~g} \mathrm{~cm}^{-2}$ $\mathrm{y}^{-1}$ and $0.030 \mathrm{~g} \mathrm{~cm}^{-2} \mathrm{y}^{-1}$ respectively. All three sites recorded small but significant increases during the second half of the twentieth century, though there were differences in timing and duration (Fig. 11c).

In the northern area of the lake the onset of increased sedimentation appears to have begun as early as the late 1920s or early 1930s (Fig. 11d), though this was from a very low base. Pre-1920 sedimentation rates were just $0.027 \mathrm{~g} \mathrm{~cm}^{-2} \mathrm{y}^{-1}$ at BW14/N1 and $0.022 \mathrm{~g} \mathrm{~cm}^{-2} \mathrm{y}^{-1}$ at BW14/N2. Later results from these two sites follow a very similar pattern, apart from an episode of accelerated sedimentation at BW14/N2 during the 1970s. Since during the same period there was a small reduction in the ${ }^{210} \mathrm{~Pb}$ supply rate at $\mathrm{BW} 14 / \mathrm{N} 1$, the difference may simply be due to a small local change in the pattern of sedimentation. Relatively few data points in BW89/5, combined with the effect of a possible slump event in the early part of the record, makes detailed comparisons with later cores difficult. The mean sedimentation rate from 1920 through to the mid-1960s $\left(0.033 \mathrm{~g} \mathrm{~cm}^{-2} \mathrm{y}^{-1}\right)$ was however very similar to that of the 2014 cores. Significantly higher post-1963 sedimentation rates are consistent with the ${ }^{137} \mathrm{Cs}$ record.

Uncertainties concerning the dry bulk density data, the relatively poor ${ }^{137} \mathrm{Cs}$ records and also the relationship between the cores analysed for ${ }^{210} \mathrm{~Pb}$ and ${ }^{137} \mathrm{Cs}$ make detailed comparisons with the 1977 study problematic. In spite of these problems, there is a general level of consistency with the later studies. The mean ${ }^{210} \mathrm{~Pb}$ supply rate $\left(311 \mathrm{~Bq} \mathrm{~m}^{-2} \mathrm{y}^{-1}\right)$ and sedimentation rate $\left(0.10 \mathrm{~g} \mathrm{~cm}^{-2} \mathrm{y}^{-1}\right)$ at the western core BWW are intermediate in value between the BW11/2 and the 1988/1989 cores BW88/2 and BW89/2, and commensurate with its intermediate location. Estimates of the mean pre-1950 sedimentation rates for the central core BWC $\left(0.041 \mathrm{~g} \mathrm{~cm}^{-2} \mathrm{y}^{-1}\right)$ are very similar to those for BW12/9 and BW88/3. There is also evidence of a post-1950 increase. The eastern (BWE) and northern (BWN) cores are however outliers in that both appear to be from sites that have experienced significantly higher sedimentation rates (and also ${ }^{210} \mathrm{~Pb}$ supply) than nearby cores from the later studies. Since both were located in relatively shallow water, these results may be due to remobilization of sediments from the margins of the lake.

\section{Discussion}

Environmental records stored in natural archives such as lake sediments are widely used for reconstructing histories of environmental change. The validity of these reconstructions rests on two fundamental issues, the existence of a clearly defined relationship between the environmental parameter being measured and the initial record created in the sediment, and the extent to which this initial record is preserved following burial under successive layers of fresh sediment. These issues are of particular importance in the case of the fallout radionuclides ${ }^{210} \mathrm{~Pb}$ and ${ }^{137} \mathrm{Cs}$ where distortion or degradation of the records would seriously reduce their value as tools for dating the sediments. Changes or disruptions to the transport processes delivering fallout ${ }^{210} \mathrm{~Pb}$ to the sediment record, caused e.g. by increased catchment inputs or changes in lake hydrology affecting the pattern of sediment focusing, can affect the relationship between the sedimentation rate and the initial ${ }^{210} \mathrm{~Pb}$ concentration (Eq. 1). Further, diagenesis can significantly affect the simple 
radioactive decay law (Eq. 5) governing the relationship between the initial and present-day concentrations.

Changes in the ${ }^{210} \mathrm{~Pb}$ supply rate can be determined using well-defined independent chronostratigraphic markers, as shown in cores BW11/2, BW88/2, BW89/ 3 , and BW14/N1, though even here account needs to be taken of the possibility that ${ }^{137} \mathrm{Cs}$ records can be influenced by the same factors as those affecting ${ }^{210} \mathrm{~Pb}$. A number of the ${ }^{137} \mathrm{Cs}$ records contain features unrelated to the 1963 and 1986 fallout events. Many early studies of ${ }^{210} \mathrm{~Pb}$ dating, recognized the potential importance of diagenetic changes caused by mixing of the surficial sediments by physical and/or biological processes. Experiments carried out by Davis (1974) on bioturbation by tubificid worms (which feed on subsurface sediments and excrete at the surface) showed that significant amounts of a pollen tracer were transported to the surface by this process. Although the greatest impact was on sediments at depths of 3-4 cm, there was a significant effect throughout the uppermost $7 \mathrm{~cm}$ and some impact on sediments as deep as $15 \mathrm{~cm}$. Similar studies by Benninger et al. (1979) on bioturbation by burrowing organisms suggested rapid mixing in the uppermost 2-3 cm of the core and lower levels of disturbance down to $10 \mathrm{~cm}$ or more. In an alternative approach taken by Moeller et al. (1984), profiles of an exotic pollen in cores collected a year after placement at the sediment/water interface showed evidence of mixing to depths ranging from 2 to $4 \mathrm{~cm}$.

A number of authors have simulated the impact of mixing on ${ }^{210} \mathrm{~Pb}$ and ${ }^{137} \mathrm{Cs}$ records, for the most part using models based on those devised by Berger and Heath (1968) and Guinasso and Schink (1975). The former assumes homogenization by rapid steady-state mixing down to a fixed mixing depth. The later assumes that mixing can be represented by a simple diffusion model within a given mixing zone. Reliable application of these models is however problematic in that they are difficult to validate, and two of their basic assumptions, a constant sedimentation rate and constant diffusivity within a constant mixing depth, are highly questionable. Furthermore, flattened ${ }^{210} \mathrm{~Pb}$ profiles in near-surface sediments that might suggest mixing can equally well be explained by changes in the sedimentation rate and/or ${ }^{210} \mathrm{~Pb}$ supply rate (Appleby 2001).
Diagenesis can also take place by diffusion or migration of a soluble component through porewaters. Evidence of ${ }^{137} \mathrm{Cs}$ mobility by this process has been observed in many studies, and is clearly demonstrated in results from annually laminated cores (Reinikainen et al. 1997) where physical mixing is negligible. High levels of fallout ${ }^{137} \mathrm{Cs}$ from the Chernobyl accident were recorded in laminae pre-dating 1986 by at least a decade. Evidence of ${ }^{210} \mathrm{~Pb}$ mobility is more difficult to come by. ${ }^{210} \mathrm{~Pb}$ concentrations in the porewaters of lake sediments were measured by Benoit and Hemond (1991), and porewater diffusion was suggested as the cause of discrepancies between observed solid phase ${ }^{210} \mathrm{~Pb}$ profiles and expected input histories.

In light of these uncertainties, reservations have continued to be expressed about the reliability of ${ }^{210} \mathrm{~Pb}$ dates. A study carried out by Kenney et al. (2016) addressed this issue directly by comparing records in sediment cores collected 14 years apart (1999 and 2013) from a shallow lake in Florida. A similar approach was taken by Klaminder et al. (2012) in a study concerned with the reliability of ${ }^{137} \mathrm{Cs}$ dates. Records from annually laminated sediment cores collected over a period of 21 years (1986 through to 2007) showed that, in spite significant levels of migration of Chernobyl ${ }^{137} \mathrm{Cs}$ down to at least the $1960 \mathrm{~s}$, peak concentrations remained firmly fixed in the 1986 varve.

The existence of two earlier multi-core studies from Brotherswater provided a unique opportunity to carry out a further study of the long-term reliability of both ${ }^{210} \mathrm{~Pb}$ and ${ }^{137} \mathrm{Cs}$ dates in a small lake typical of those used in many paleolimnological studies. The ${ }^{137} \mathrm{Cs}$ records shown in Figs. 2, 3, 4 and 5 provide clear and direct evidence of the preservation and progressive burial of environmental records stored in the sediments of Brotherswater and, in this case, the reduction in concentration due to radioactive decay. The persistence over time of a relatively good agreement between ${ }^{210} \mathrm{~Pb}$ dates calculated in this case using the CRS model, and chronostratigraphic dates determined from the ${ }^{137} \mathrm{Cs}$ records, provides evidence of the relative stability of ${ }^{210} \mathrm{~Pb}$ records. Differences between ${ }^{210} \mathrm{~Pb}$ and ${ }^{137} \mathrm{Cs}$ dates were relatively small at sites in the lake where the ${ }^{210} \mathrm{~Pb}$ supply rate was comparable to the atmospheric flux. Discrepancies were however observed at sites where ${ }^{210} \mathrm{~Pb}$ supply rates significantly exceeded the atmosphere flux. Calculations of pre1963 and post- $1963{ }^{210} \mathrm{~Pb}$ supply rates showed that these discrepancies were attributable to changes in the 
${ }^{210} \mathrm{~Pb}$ supply rate due to causes such as varying allochthonous inputs from the catchment and varying degrees of sediment focusing within the lake. Since the changes in sedimentation rates at these sites were not proportional to changes in the ${ }^{210} \mathrm{~Pb}$ supply rates, in these cases neither of the standard simple (CRS and CIC) models were applicable to the ${ }^{210} \mathrm{~Pb}$ record as a whole. Reliable chronologies spanning the ${ }^{210} \mathrm{~Pb}$ period could however be constructed by applying these models in a piecewise way to different sections of the core. Although there were differences in detail, pre-1989 sedimentation rates determined from the recent study were generally similar to those determined for similar areas of the lake in the earlier studies. This was not however the case for cores from the western side of the lake heavily impacted by catchment inputs where there were large differences between cores separated by relatively short distances.

Open Access This article is distributed under the terms of the Creative Commons Attribution 4.0 International License (http:// creativecommons.org/licenses/by/4.0/), which permits unrestricted use, distribution, and reproduction in any medium, provided you give appropriate credit to the original author(s) and the source, provide a link to the Creative Commons license, and indicate if changes were made.

\section{References}

Appleby PG (2001) Chronostratigraphic techniques in recent sediments. In: Last WM, Smol JP (eds) Tracking environmental change using lake sediments, vol 1. Basin analysis, coring, and chronological techniques. Kluwer Academic, Dordrecht, pp 171-203

Appleby PG, Oldfield F (1978) The calculation of lead-210 dates assuming a constant rate of supply of unsupported ${ }^{210} \mathrm{~Pb}$ to the sediment. CATENA $5: 1-8$

Appleby PG, Nolan PJ, Gifford DW, Godfrey MJ, Oldfield F, Anderson NJ, Battarbee RW (1986) Pb-210 dating by lowbackground gamma counting. Hydrobiologia 143:21-27

Appleby PG, Richardson N, Nolan PJ (1991) ${ }^{241}$ Am dating of lake sediments. Hydrobiologia 214:35-42

Appleby PG, Richardson N, Nolan PJ (1992) Self-absorption corrections for well-type germanium detectors. Nucl Instrum Methods B 71:228-233

Benninger LK, Aller RC, Cochran JK, Turekian KK (1979) Effects of biological sediment mixing on the ${ }^{210} \mathrm{~Pb}$ chronology and trace metal distribution in a Long Island Sound sediment core. Earth Planet Sci Lett 43:241-259

Benoit G, Hemond HF (1991) Evidence for diffusive redistribution of ${ }^{210} \mathrm{~Pb}$ in lake sediments. Geochim Cosmochim Acta 55:1963-1975

Berger WH, Heath GR (1968) Vertical mixing in pelagic sediments. J Marine Res 26:134-143
Bonnett PJP, Appleby PG, Haworth EY, Hilton J, Davison W, Oldfield F (1992) Environmental behaviour of radioactivity from Chernobyl: Brotherswater study. In: DOE report no. DOE/RAS/92.004

Boyle JF (1995) A simple closure mechanism for a compact, large-diameter, gravity corer. J Paleolimnol 13:85-87

Davis R (1974) Stratigraphic effects of tubificids in profundal lake sediments. Limnol Oceanogr 19:466-488

Eakins JD, Cambray RS, Chambers KC, Lally AE (1981) The transfer of natural and artificial radionuclides to Brotherswater from its catchment. In: AERE-R 10375. AERE Harwell, UK

Eakins JD, Cambray RS, Chambers KC, Lally AE (1984) The transfer of natural and artificial radionuclides to Brotherswater from its catchment. In: Haworth EY, Lund JW (eds) Lake sediments and environmental history. Leicester University Press, Leicester, pp 94-114

Guinasso NL, Schink DR (1975) Quantitative estimates of biological mixing rates in abyssal sediments. J Geophys Res 80:3032-3043

Hilton J, Haworth EY, Davison W, Kelly M, Hamilton-Taylor J, Appleby PG (1992) Transport processes of ${ }^{137} \mathrm{Cs}$ in lake environments. In: DOE/RW/92.005

Kenney WF, Brenner M, Arnold TE, Curtis JH, Schelske CL (2016) Sediment cores from shallow lakes preserve reliable, informative paleoenvironmental archives despite hurricane-force winds. Ecol Indic 60:963-969

Klaminder J, Appleby P, Crook P, Renberg I (2012) Post-deposition diffusion of ${ }^{137} \mathrm{Cs}$ in lake sediment: implications for radiocesium dating. Sedimentology 59:2259-2267

Maberly S, De Ville M, Thackeray S, Feuchtmayr H, Fletcher JM, James JB, Kelly JL, Vincent CD, Winfield IJ, Newton A, Atkinson D, Croft A, Drew H, Saag M, Taylor S, Titterington $H$ (2011) A survey of the lakes of the English Lake district: the lakes tour 2010. In: Final report to the environment agency, Northwest region

Moeller RE, Oldfield F, Appleby PG (1984) Biological sediment mixing and its stratigraphic implication in Mirror Lake (New Hampshire, U.S.A.). Verh Internat Verein Limnol 22:567-572

Pennington W (1981) Records of a lake's life in time: the sediments. Hydrobiologia 79:197-215

Reinikainen P, Meriläinen JJ, Virtanen A, Veijola H, Äystö J (1997) Accuracy of ${ }^{210} \mathrm{~Pb}$ dating in two annually laminated lake sediments with high Cs background. Appl Radiat Isot 48:1009-1019

Robbins JA (1978) Geochemical and geophysical applications of radioactive lead. In: Nriagu JO (ed) Biogeochemistry of lead in the environment. Elsevier Scientific, Amsterdam, pp 285-393

Schillereff DN, Chiverrell RC, Macdonald N, Hooke JM, Welsh KE (2016) Quantifying system disturbance and recovery from historical mining-derived metal contamination at Brotherswater, northwest England. J Paleolimnol 56:205-221. https://doi.org/10.1007/s10933-016-9907-1

Semertzidou P (2018) The distribution and transport of the natural fallout radionuclide ${ }^{210} \mathrm{~Pb}$ in the atmosphere and through catchment/lake systems. Unpublished Ph.D. Thesis, University of Liverpool

Smith JN (2001) Why should we believe ${ }^{210} \mathrm{~Pb}$ sediment geochronologies. J Environ Radioact 55:121-123 